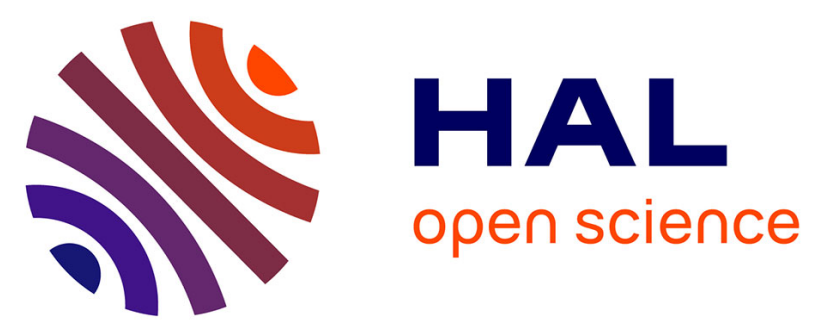

\title{
Increasing food production and mitigating agricultural greenhouse gas emissions in the European Union: impacts of carbon pricing and calorie production targeting
}

\author{
Ancuta Isbasoiu, Pierre-Alain Jayet, Stéphane de Cara
}

\section{To cite this version:}

Ancuta Isbasoiu, Pierre-Alain Jayet, Stéphane de Cara. Increasing food production and mitigating agricultural greenhouse gas emissions in the European Union: impacts of carbon pricing and calorie production targeting. Environmental Economics and Policy Studies, 2021, 23, pp.409-440. 10.1007/s10018-020-00293-4 . hal-03151982

\author{
HAL Id: hal-03151982 \\ https://hal.inrae.fr/hal-03151982
}

Submitted on 25 Feb 2021

HAL is a multi-disciplinary open access archive for the deposit and dissemination of scientific research documents, whether they are published or not. The documents may come from teaching and research institutions in France or abroad, or from public or private research centers.
L'archive ouverte pluridisciplinaire HAL, est destinée au dépôt et à la diffusion de documents scientifiques de niveau recherche, publiés ou non, émanant des établissements d'enseignement et de recherche français ou étrangers, des laboratoires publics ou privés.

\section{(1)(1) $\$(0)$}

Distributed under a Creative Commons Attribution - NonCommercial - ShareAlikel 4.0 


\title{
Increasing food production and mitigating agricultural greenhouse gas emissions in the European Union: impacts of carbon pricing and calorie production targeting
}

\begin{abstract}
This study focuses on the links between food production and greenhouse gas emissions in the European Union. The analysis relies on two sets of simulations of AROPAj, a supply-side model of EU agriculture: (i) a carbon price affecting agricultural GHG emissions (from 0 to $200 \mathrm{EUR} / \mathrm{tCO} 2 \mathrm{eq}$ ), and (ii) a lower limit on the net quantity of food calories provided by EU agriculture (200 to $450 \mathrm{Mt}$ soft wheat equivalent). The model is calibrated on six annual datasets 2007-2012. The results show that a moderate increase in the price of carbon would lead to an increase in total areas and outputs of crops. Animal production decreases over the explored range of carbon price. At $200 \mathrm{EUR} / \mathrm{tCO}$ eq, the reduction in $\mathrm{GHG}$ emissions ranges from 25 to $35 \%$ depending on the year of calibration. The results also show that current net calorie production from food can be more than doubled, while simultaneously reducing GHG emissions by $10-15 \%$. The compatibility between a reduction in GHG emissions and an increase in food calorie production relies on substantial changes in animal production and feed, which implies significant variations in grassland and fallow land. These effects are contrasted between the regions of the EU.
\end{abstract}

Keywords: greenhouse gas emissions; food production; carbon price; European Union; mathematical programming model

JEL Classification: Q18; Q54

\section{Introduction}

One of the major challenges of the 21st century is to ensure an appropriate and viable food system (United Nations, 2015) while simultaneously reducing negative impacts on the environment (Garnett, 2011). Relationships between agriculture, climate change, and the environment are at the center of these debates in the scientific literature (Foley et al., 2011; Godfray, 2014; Meijl et al., 2018; Röös et al., 2017; Gregory et al., 2005; Ludi, 2009; Deering, 2014; Frank et al., 2017; Devereux \& Edwards, 2004; Beddington et al., 2012; Wilkes et al., 2013). Agriculture is one of the productive activities most affected by climate change and, at the same time, must be an integral part of any strategy to mitigate global anthropogenic GHG emissions. To achieve the objective set by the Paris Agreement to limit global warming to $2^{\circ} \mathrm{C}$, the analysis of the mutual relationship between climate change and agricultural production is of major interest. The dynamics of agricultural development are a result of the growing demand for food at the global level, with Europe being one of the main producers and suppliers of food globally. Therefore, a critical issue is to increase (or at least maintain) European agricultural production while preserving natural and environmental resources (European Commission, 2009, 2013, 2017; HLPE, 2012).

Agriculture, through its activities, emits substantial quantities of methane $\left(\mathrm{CH}_{4}\right)$ and nitrous oxide $\left(\mathrm{N}_{2} \mathrm{O}\right)$ into the atmosphere, of which approximately $45 \%$ comes from enteric fermentation; $37 \%$ are from agricultural soils; $15 \%$ are linked to manure management; and, 3\% 
are from rice cultivation, field burning of agricultural residues, and other sources. In 2017, the greenhouse gas (GHG) emissions from European agriculture were $440 \mathrm{MtCO}_{2} \mathrm{eq}$ (European Environment Agency, 2019). Carbon pricing plays an essential and indispensable role in achieving substantial GHG emissions mitigation ${ }^{1}$. The challenge lies in both addressing multiple environmental and social objectives and in fostering an effective reduction in the costs of obtaining them (World Bank and Ecofys, 2018; Aldy \& Stavins, 2012; OECD, 2015; Vojtech, 2010).

Beyond the overall reduction in GHG emissions that may be achieved at a certain emission price, the quantity and quality of total output as well as the distribution of impacts across farm types (e.g., crop vs. livestock production), land area allocation (food crops vs. feed crops vs. grassland) are also of great importance for policy design (Leip et al., 2010; Olesen \& Bindi, 2002). Given that livestock represents one of the major sources of emissions, and, at the same time, accounts for one-third of the protein in human food, climate mitigation policies involving livestock play an essential role. Animal rearing involves using 30\% of the global land surface, land saving can be realized by increasing livestock productivity through feeding practices that require, among other things, an improved grassland management, less grazing, and better quality feeds. According to Gerber et al. (2013), the livestock sector must be seen as a solution to climate change, and its significant emissions can be reduced through mitigation measures that meet environmental objectives. At the same time, the livestock sector plays a key role in food security, by 2050 the demand for livestock products being projected to increase by $70 \%$, which raises concerns about the impacts of a potential imbalance between this growth and the economic and environmental effects that may occur. The global-scale results obtained by Havlík et al. (2014) suggest that mitigation policies targeting emissions from land-use change are more effective than those targeting emissions from livestock only. Berners-Lee et al. (2018) argue that industrialized meat and milk production accounts for $34 \%$ of global human calories but is highly inefficient in supplying energy, proteins, iron, and zinc, indispensable to humans and that it is incompatible with a sustainable food system. According to West et al. (2014), crops used for animal feed could produce a substantial gain in calories (approximately 70\%) if they were intended for direct consumption instead of being used as animal feed to produce animal products, meat and milk.

The connection between mitigation of GHG emissions and food calorie target leads to the need for an assessment that accounts for the impact of GHG emission pricing on food production in the EU, the interactions between crop and livestock production activities, and the evaluation of existing Common Agricultural Policy (CAP) policy instruments. To address the trade-offs that may arise, FAO $(2003 \mathrm{~b}, 2009)$ highlights the importance of the costs needed to achieve food production and climate change mitigation.

A quantitative evaluation of marginal abatement costs in the EU agricultural sector was conducted by De Cara \& Jayet (2011), underlining the effects of the EU burden-sharing agreement on this sector. A $10 \%$ EU GHG abatement target can be achieved at an emission price range of EUR 32-42/tCO reduction in a cost-effective way. Frank et al. (2017) highlight the substantial impacts that a global uniform carbon price can have on food security and its inequitable effects across sectors of the economy and regions. Thus, they show that food security is more strongly affected in countries that do not engage in mitigation actions, with the costs of agricultural production rising with inefficient mitigation.

According to Sonesson et al. (2010), a significant share of total GHG emissions at the global level is linked to the food chain, stressing that the choice of products (i.e. diets) represents one the main elements aimed at reducing the impact of food on climate change. Bajzelj et al. (2014) assess the environmental consequences of an increasing demand for food by 2050. They emphasize the search for alternatives guaranteeing global food security without expanding

\footnotetext{
${ }^{1}$ There are two main ways to introduce carbon pricing: carbon taxes and cap-and-trade systems. Both of these carbon pricing instruments have been presented as an important factor in incentivizing the mitigation of GHG emissions and promoting investment in low emission technologies and practices (OECD and WBG, 2015; Kossoy et al., 2015; The Grantham Research Institute, 2011).
} 
crops or pastures and without increasing GHG emissions. In a reference scenario which considers a population level of 9.6 billion by 2050 , they estimate that the average food consumption per capita would increase to $2710 \mathrm{kcal} /$ day (including $470 \mathrm{kcal} /$ day for livestock products). In such a scenario, if emission mitigation strategies are not implemented, an intensification of livestock and large-scale expansion of cropland would lead to an increase of about $77 \%$ in agricultural greenhouse gas emissions, due to the increase in food demand, the share of emissions from livestock and deforestation. Scenarios based on a healthy diet would have the effect of reducing cultivated areas by around $5 \%$, pastures by around $25 \%$ and greenhouse gas emissions by around $45 \%$, mainly linked to the reduction in herds. They point out that mitigation strategies could be based on economic incentives such as a carbon tax. The need for mitigation strategies aimed at balancing food production and GHG emissions is emphasized by McAllister et al. (2011), in order to make a growing global demand for food partly satisfied by livestock products compatible with the control of environmental impacts. According to Tilman \& Clark (2014), other factors are necessary for agriculture to become environmentally sustainable. The more efficient use of feed and pasture for animal production and of fertilizer or irrigation for crops would increase food production and decrease GHG emissions. With linear programming, van Kernebeek et al. (2016) propose a model for optimizing land use including animal and plant production. They show that the optimal amount of dietary protein from animals in the human diet depends on both the size of the population and the relative share of land unsuitable for agricultural production.

Our study extends the vision of the connection between agricultural production and reducing GHG emissions in the European Union (EU) through two different analysis perspectives. First, we use a price approach targeting a reduction of GHG emissions through the introduction of a carbon price. The second perspective constitutes a constraint approach, through the introduction of a minimum supply of food calorie constraint imposed on European agriculture as a whole. In addition, we take into consideration the economic context variability characterizing EU agriculture, based on six years (2007-2012) marked by a strong variation in input and output prices.

On the production side, we focus on cereals. Let us recall that, in 2013 (European Commission, 2014), one-third of the EU agricultural area was cultivated with cereals, whose value represented one-eighth of the total value of EU agricultural products. The annual EU cereal production varied significantly in time, between 266 and 321 Mt over 2007-2012, as a result of both the economic and meteorological context, peaking in $2008^{2}$.

Long-run climate policies should ensure that the strongly changing agricultural economy is not disrupted beyond what pertains to the environmental target. The period from 2007-2012, on which our study is based and against which the model is calibrated due to data availability, shows how rapidly the economic context may change in terms of prices and productions.

By using the European agro-economic AROPAj model, we analyze the compatibility of environmental objectives and food production, through two different approaches (pricing and binding), but with the same methodological framework. An accurate analysis of the GHG emission reduction and, implicitly, the marginal abatement cost curves are conducted in a separate study. Thereby, the objectives of this study are twofold: (i) to assess the consequences of a carbon price introduction on the crop and livestock production in the EU, and (ii) to assess the effects of introducing a food production target on the EU agricultural GHG emissions.

In doing so, we consider the position of two decision-makers, one focused on the objective of food production and the other on direct emissions of $\mathrm{N}_{2} \mathrm{O}$ and $\mathrm{CH}_{4}$ from agriculture. Among the major results of our article, we show that a carbon price has a different impact on plant and animal production. A moderate increase in the price of carbon leads to an increase in crop production - especially cereals and oilseeds -, the magnitude of which varies between products and Member States. This increase concerns both the areas and the quantities of plant products, whether marketed or used as animal feed on farms. On the other hand, the production of milk and meat decreases with the price of carbon over the entire range explored. Then, calorie targets

\footnotetext{
${ }^{2}$ World Bank data https://data.worldbank.org
} 
are introduced from 200 to 400Mt of soft wheat equivalent. For the respective values of 300, 350 and $400 \mathrm{Mt}$, the marginal costs associated with them vary from year to year in the ranges [20, 36], [27, 52] and [36, 94] euros per tonne of soft wheat equivalent. These effects reflect complex substitutions in crops, grasslands and forages and are related to animal feed. The results show that the reduction in GHG emissions is compatible with the increase in food production for the benefit of agricultural products and to the detriment of livestock products. The impacts of pricing GHG emissions (price-based approach) or a food calorie production target (threshold-based approach) result in a sharp decrease in grass areas, partially offset by an increase in the area of crops sold but also by a significant increase in fallow areas.

The rest of this article is organized as follows: section 2 begins with a brief presentation of the AROPAj model, followed by a description of the two angles of analysis undertaken in the study, namely the price approach with pricing of GHG emissions and the constraint approach with the setting of a target for the production of food calories. The results obtained are examined in section 3. The discussion on the scope of the results and their political implications is highlighted in section 4 . The concluding remarks are presented in section 5.

\section{Methodological elements}

\subsection{General framework - AROPAj model}

Our analysis is based on the use of a supply-side model capable of integrating both the economic and technical connections between the agricultural sector, climate, and GHG emissions as a tool for strategic decision-making. The European agro-economic model AROPAj is based on linear programming (LP). It aims to simulate the EU agricultural supply by taking into consideration the production derived from main crops and livestock ${ }^{3}$. The model has been widely used in previous studies of agricultural and/or environmental policies (De Cara et al., 2005; Galko \& Jayet, 2011; De Cara \& Jayet, 2011; De Cara et al., 2018).

The model parameters are estimated from the annual Farm Accountancy Data Network (FADN), which allows using the model for all EU Member States. FADN possesses accounting information on approximately 80,000 agricultural holdings, totaling approximately 5 million farms in the EU. The model covers approximately $85 \%$ of the holdings, $90 \%$ the total utilized agriculturalarea (UAA) and the EU total agricultural production. ${ }^{4}$ One of the strengths of the AROPAj model is its capacity of simultaneously incorporating crops, livestock, grassland, and feed (both on-farm and marketed feed).

To form a unit of the AROPAj model for a given year,a clustering method is employed, allowing us to group the farms in the FADN into representative farms ${ }^{5}$. The number of farms modeled is reduced due to the protection of individual data, the statistical quality of the parameter estimation and calculation costs, while representing the great diversity of the EU agricultural sector. According to the years, AROPAj is declined in 1800 to 1950 representative farms. Each of them represents from a few tens to a few thousand real farms. Representativeness is determined by the weighting system proposed in the FADN, which associates a weight with each farm in the sample.

In the model, each representative farm $k$ has the objective of maximizing the total gross

\footnotetext{
${ }^{3} \mathrm{An}$ entire technical presentation of the model is available at https://www6.versaillesgrignon.inra.fr/economie_publique/Media/fichiers/ArticlAROPAj

${ }^{4}$ For a detailed description of FADN data, see: http://ec.europa.eu/agriculture/rica/

${ }^{5}$ Four key variables are used: FADN-defined type of farming (12 TF), altitude (3 levels), irrigation (share of area) and economic size (10 classes).
} 
$\operatorname{margin} \pi_{k}$ :

$$
\begin{aligned}
& \max _{x_{k}} \pi\left(x_{k}, \theta_{k}, \phi\right) \\
& \text { s.t. } x_{k} \in \mathscr{A}_{k}\left(\theta_{k}, \phi\right)
\end{aligned}
$$

where $x_{k}$ represents the vector of endogenous activities depending, at the optimum, on specific parameters $\theta_{k}$ and general parameters $\phi$. Among many other activities, the vector $x_{k}$ include cropspecific variables such as areas, marketed quantities and on-farm used quantities. It also includes animal activities broken down into several categories (more detailed for cattle) and the production of meat and milk. The vector $\theta_{k}$ refers to $k$-specific parameters and the vector $\phi$ refers to common parameters such as GHG price. The production set $\mathscr{A}_{k}$ represents the combinations of values of the $x_{k}$ components respecting a set of inequalities expressed linearly against to components. Among the set of constraints, we mention quasi-fixed factor limits such as UAA and livestock,crop rotation constraints, animal feed requirements (met from on-farm produced cereals, purchased concentrates and forage or meadows) and the implementation of the Common Agricultural Policy instruments.

The calibration of the AROPAj model consists in re-estimating the values of a subset of parameters for which the preliminary values are considered fragile. It sequentially combines Monte Carlo-type random drawing methods and gradient methods. The principle consists in estimating the value of the parameters $\theta_{k}$ which minimizes a criterion of distance between the LP solution $x_{k}^{*}\left(\theta_{k}, \phi_{0}\right)$, given the present-time economic context $\phi_{0}$, and the "observed" values corresponding to these variables (estimated directly from the FADN). In practice, the method involves a subset of 120 to 150 parameters mainly concerning animal feed (inputs and needs), and the criterion is the sum of the squares of the deviations concerning in particular the areas for crops and the numbers of different animal categories. It is applied for each representative farm and for each of the years of the FADN.

AROPAj includes 32 crop productions and 28 animal productions. Crop producing activities utilize a large part of the EU agricultural land, the crops being divided into three categories: (i) crops that can be either sold or consumed on-farm (i.e., cereals), (ii) crops that can be only consumed on-farm (e.g., fodder and pastures), and (iii) crops intended for sale. As regards animal production, the model includes a large variety of animals (24 categories of cattle and 4 other categories: sheep, pigs, goats, and poultry).

Livestock may be adjusted within a chosen amplitude. The adjustment limit refers to a few animal categories. These categories are, separately, swine, poultry, sheep, goats and four bovine categories, namely dairy cows, non-dairy cows, bulls and oxen. Other animal categories included in the model referring to calves and young animal differentiated by age, sex, and dairy or non-dairy may freely adjust when accounting for the inter-age balance. Our results are derived from simulations based on a amplitude limit of $+/-25 \%$ applying to FADN sourced estimates. For the $i$-animal categories concerned, this limit $(\alpha)$, called livestock adjustment ratio thereafter, is integrated into linear programming in the form $\left|L_{i}-L_{i 0}\right| \leq \alpha L_{i 0}$.

For ruminants (cattle, in particular), reducing GHG emissions involves the improvement of the efficiency of animal husbandry through the use of fodder and better feed formulation that can reduce the $\mathrm{CH}_{4}$ generated during digestion, and the $\mathrm{CH}_{4}$ and $\mathrm{N}_{2} \mathrm{O}$ produced by manure decomposition. Grasslands play an important role in mitigating GHG emissions and achieving food security, given the fact that meat and milk production depends on ruminants feeding. Climatic conditions, rainfall and temperature distribution, and soil characteristics are among the main factors influencing the grassland spatial distribution and productivity (O'Mara, 2012; Huyghe et al., 2014). $\mathrm{CH}_{4}$ emissions depend on the number of animals and the composition of animal feeding. $\mathrm{CH}_{4}$ from enteric fermentation depends directly on animal feeding, which must meet all the requirements in terms of energy and proteins. This is achieved by including various types of feeds in the model: concentrated feeds, crop products, and raw feeds. A certain intake of energy and proteins is necessary for each animal species, depending on different factors, such as age, daily activity, physical condition, and potential production. In the model, animal feeding is endogenous 


\footnotetext{
${ }^{6}$ For each of the years, the model is delineated through more than 1,700 and up to more than 1,900 representative farms.
}

and farmers have the choice to use either fodder feed from their own crops or purchased concentrates. The reduction in $\mathrm{N}_{2} \mathrm{O}$ emissions from agriculture is mainly the result of improving the efficiency of agricultural techniques related to manure application, storage, and management, as well as that of soil and crop use techniques (Smith et al., 2008, 2013).

In the model, emissions are obtained according to the Intergovernmental Panel on Climate Change (IPCC) Guidelines (IPCC, 2006), allowing inter-country comparisons. In particular, the model relies on country-specific activity data and emission factors. The IPCC parameters for each EU Member State can be found in the respective National Report of GHG Inventories, submitted on a yearly basis to the United Nations Framework Convention on Climate Change. AROPAj relies on the following agricultural emission sources: $\mathrm{N}_{2} \mathrm{O}$ emissions from agricultural soils and manure management, and $\mathrm{CH}_{4}$ emissions from manure management, enteric fermentation, and rice cultivation (refining and updating the results of De Cara et al. (2005)). $\mathrm{N}_{2} \mathrm{O}$ emissions from agricultural soils are subdivided into: (i) direct emissions: use of synthetic fertilizers, manure application, biological $\mathrm{N}$ fixation, crop residues and animal production; (ii) indirect emissions: atmospheric deposition, and leaching and run-off. Our calculations depend on these 11 emission sources, which are directly associated with the IPCC data.

Our results are based on the most recent version of the model calibrated against six sets of annual data (FADN data for the period from 2007 to 2012). Each FADN year refers to a specific farm clustering into representative farms ${ }^{6}$, which allows the representation of six economic situations of European agriculture. The six-year period on which our study is based is very diverse, with agricultural and energy prices that exhibit strong variations.

\subsection{Carbon price implementation}

When a carbon tax is introduced, representative farms may behave in various ways to reduce their emissions, by reducing their number of animals or by changing area allocations among crops or modifying animal feeding. We introduce a pricing of GHG emissions weighted according to GHG Global Warming Potential, considering the direct emissions of $\mathrm{N}_{2} \mathrm{O}$ and $\mathrm{CH}_{4}$ from agriculture. In AROPAj, the carbon price introduced ranges widely, from 0 to $10,000 € / \mathrm{tCO}_{2} \mathrm{eq}$, in gradual steps. Simulations are conducted by using 200 values selected from this range, when the livestock adjustment ratio is of $25 \%$. They are carried out for the six FADN years for which the AROPAj model operates.

To obtain a relatively broad view of the impacts of emission taxing on the production system and reach valid conclusions, we have decided to introduce a carbon price (expressed in $€ / \mathrm{tCO}_{2}$ equivalent) ranging in the interval $[0,200]$, a relatively wide price range, but "realistic" at the same time. These prices are in line with those in previous studies (De Cara et al., 2005; De Cara \& Jayet, 2011). At the same time, a price higher than $100 € / \mathrm{tCO}_{2}$ is relevant when referring to climate policies. In Sweden, the carbon tax represents the most powerful instrument of the Swedish climate policy since 1991 and is currently at $120 € / \mathrm{tCO}_{2}$ eq (Adelphi, 2018).

From this angle of analysis and, more precisely, in what we call the price approach, the study aims to discover the potential impacts of an emission tax on agricultural commodities brought to the market, with the model applied to very diverse economic conditions, given the strongly changing 2007-2012 prices of inputs and outputs. By using the AROPAj model, we assess the potential effects on crop and livestock production in the EU when a carbon price is introduced and analyze the trade-off between and within these type of productions at the European level and the environment, as results of policies targeting GHG emissions. 
Table 1. Calorie content of products exported from farms (FAO, 2003a); the content is weighted by the life duration of animals in each category (in years), as estimated for the AROPAj model.

\begin{tabular}{|c|c|c|c|c|}
\hline Crops & $\begin{array}{l}\text { Calorie content } \\
\text { [kcal/100g] }\end{array}$ & Animal category & $\begin{array}{l}\text { Calorie content } \\
{[\mathrm{kcal} / \mathbf{1 0 0 g}]}\end{array}$ & $\begin{array}{l}\text { Meat content } \\
\text { [ton/animal/year] }\end{array}$ \\
\hline oats & 385 & two-year-old males on-farm & 250 & 0.48 \\
\hline durum wheat & 334 & female calves from dairy herd* & 250 & 0.27 \\
\hline soft wheat & 334 & female calves from breeding herd* & 250 & 0.27 \\
\hline maize & 356 & 18-month-old bulls & 250 & 0.4 \\
\hline other cereals & 340 & 8-day old slaughtered calves & 250 & 0.1 \\
\hline barley & 332 & two-month-old slaughtered calves & 250 & 0.25 \\
\hline rye & 319 & dairy cows & 250 & 0.036 \\
\hline rice & 362 & six-month-old calves (field) & 250 & 0.27 \\
\hline A-sugar & 70 & suckler cows & 250 & 0.080 \\
\hline B-sugar & 70 & goats & 210 & 0.012 \\
\hline C-sugar & 70 & sheep & 210 & 0.012 \\
\hline sugar beet & 70 & pigs & 220 & 0.26 \\
\hline field vegetables & 40 & poultry & 200 & 7.5 \\
\hline proteins & 80 & milk** & 61 & \\
\hline potatoes & 67 & & & \\
\hline & 335 & & & \\
\hline protein fodder & 387 & & & \\
\hline rapeseed & 387 & concentrated feed & 350 & \\
\hline sunflower & 387 & raw feed & 80 & \\
\hline
\end{tabular}

* non reported on farm;
** distinct category, as animal product

* non reported on farm;
** distinct category, as animal product

The binding approach refers to the integration of a food calorie production target. For easier interpretation, the threshold introduced was based on calorie quantities expressed in tons of soft wheat equivalent (tsweq). Thus, the estimation of the food parameters was done by using the database provided by FAO (2003a). The calorie target is introduced as a bound affecting the net sum of calories emanating from marketed crops, milk, and meat related to sold animals, and from bought concentrated feed in all representative farms combined. The constraint binding all these representative farms was the calorie balance, including the calorie content of different crops and livestock productions (see Table 1). In the case of crop productions, the data were used in raw form. For animal productions, given that AROPAj takes into account live animals, it was necessary to convert meat into calories. We considered only exported or marketed animals and, thus, took into account the animals' lifetime, with the meat content weighted by referencing AROPAj units. Calories used in animal feed are counted negatively in the net balance of calories produced by the system. Simulations are performed for the years 2007-2012 when the livestock adjustment ratio is of $25 \%$.

We needed to modify some calculations in our programming tools, as the target affects the European farming system as a whole. The kernel of the model was improved to integrate and parameterize this threshold. We started from the reference level and we increased the value of the target to the maximum level allowing the existence of a solution. In this constraint approach, the target varies from the unbounded case up to the feasibility limit. From a technical point of view, the indexation of the representative farms was modified automatically. All these steps were based on a sub-aggregation of AROPAj representative farms by country, and a re-indexation of representative farms that allows dealing with the solution directly. We did preliminary work dedicated to scriptwriting and prepared code to obtain the results, with very large files processed in reasonable time, which allowed us to obtain the desired results.

Mathematical programming models make it possible to estimate the implicit value of a

\subsection{Implementation of food calorie target}


resource, which is zero when it is not limiting and positive. If not, this will be used to evaluate the marginal value of calorie production.

\section{Result}

\subsection{Carbon pricing impact}

We focus on cereal area and production while distinguishing its marketed output and onfarm use as feed, oilseeds production and area, livestock, feed quantity, nitrogen fertilizer consumption, grasslands, and fallows.

Large differences between the results in each year reflect the strong variation of agricultural prices and climatic conditions during the period. A moderate carbon price leads to a strong variation in the abatement rate (from $10 \%$ to $16 \%$ when the price is EUR 50, and from $16 \%$ to $25 \%$ when the price is EUR 100). However, the estimated emissions exhibit a narrower spread (13 Mt $\mathrm{CO}_{2}$ eq based on the interval $[318,331]$ when the price is EUR 50, and $19 \mathrm{Mt}$ based on $[289,308]$ when the price is EUR 100). The spread of the abatement rate across the years ranges from $25 \%$ to $39 \%$, with an emission spread of $34 \mathrm{Mt}$ when the price is $200 € / \mathrm{tCO}_{2} \mathrm{eq}$ (see Table 2).

Table 2. EU aggregate values (initial emission level, emissions, and abatement level and rate), for each of the six years (2007-2012) and for different emission tax levels EUR 0, 50, 100, and 200.

\begin{tabular}{c|c|cccccc} 
Carbon price (€) & & $\mathbf{2 0 0 7}$ & $\mathbf{2 0 0 8}$ & $\mathbf{2 0 0 9}$ & $\mathbf{2 0 1 0}$ & $\mathbf{2 0 1 1}$ & $\mathbf{2 0 1 2}$ \\
\hline 0 & Initial emission level $\left[\mathrm{MtCO}_{2} \mathrm{eq}\right]$ & 391.3 & 355.5 & 366.2 & 387.0 & 367.0 & 366.6 \\
\hline \multirow{3}{*}{50} & Emissions $\left[\mathrm{MtCO}_{2} \mathrm{eq}\right]$ & 327.2 & 320.0 & 318.1 & 323.3 & 331.2 & 331.0 \\
& Abatement $\left[\mathrm{MtCO}_{2} \mathrm{eq}\right]$ & 64.1 & 35.6 & 48.2 & 63.8 & 35.8 & 35.7 \\
& Abatement rate $(\%)$ & $16 \%$ & $10 \%$ & $13 \%$ & $16 \%$ & $10 \%$ & $10 \%$ \\
\hline \multirow{3}{*}{100} & Emissions $\left[\mathrm{MtCO}_{2} \mathrm{eq}\right]$ & 294.0 & 296.8 & 289.4 & 291.4 & 307.7 & 307.8 \\
& Abatement $\left[\mathrm{MtCO}_{2} \mathrm{eq}\right]$ & 97.3 & 58.8 & 76.9 & 95.6 & 59.3 & 58.9 \\
& Abatement rate $(\%)$ & $25 \%$ & $17 \%$ & $21 \%$ & $25 \%$ & $16 \%$ & $16 \%$ \\
\hline \multirow{3}{*}{200} & Emissions $\left[\mathrm{MtCO}_{2} \mathrm{eq}\right]$ & 239.1 & 260.5 & 239.0 & 240.0 & 267.2 & 273.4 \\
& Abatement $\left[\mathrm{MtCO}_{2} \mathrm{eq}\right]$ & 152.2 & 95.0 & 127.3 & 147.5 & 99.8 & 93.2 \\
& Abatement rate $(\%)$ & $39 \%$ & $27 \%$ & $35 \%$ & $38 \%$ & $27 \%$ & $25 \%$ \\
\hline
\end{tabular}

The annual changes in emission prices should be explained by contrasting annual sets of agricultural input and output prices, when quasi-fixed factors (UAA and livestock) are relatively stable (i.e., when the initial livestock spread is less than $3 \%$ of the six-year average and the UAA spread is approximately $1 \%$ of the six-year average).

For the EU, the variation of the main crop and livestock productions when the carbon price changes, as well as the envelope curve drawn for each of these agricultural productions, are illustrated in Figure 1. For each year, a series of simulations to account for the GHG price change are performed while keeping global economic and climatic conditions constant, based on the conditions of each FADN year. An increase in the carbon price expectedly leads to a decrease in GHG emissions and impacts agricultural supply differently.

The marketed cereal production varies in each FADN year as the carbon price increases, exhibiting a notable peak often appearing in the retained carbon price interval (Figure 1c). The peak strongly changes in terms of cereal quantity and price limit from one year to the other. The most significant result is that there is a peak in each of the six years (although it lies out of the price scope for three of them: 2007, 2011, and 2012). In 2009, for example, the marketed cereal production increases smoothly up to a price limit maximum $\left(44 € / \mathrm{tCO}_{2}\right)$ and then strongly decreases when the carbon price exceeds this limit.

By extending the analysis to cereal area ${ }^{7}$, we observe that, in each year, the peak's price

\footnotetext{
${ }^{7}$ In AROPAj, the cereal area includes the main cereal crops: durum wheat, soft wheat, barley, maize, oats, rye, and
} 

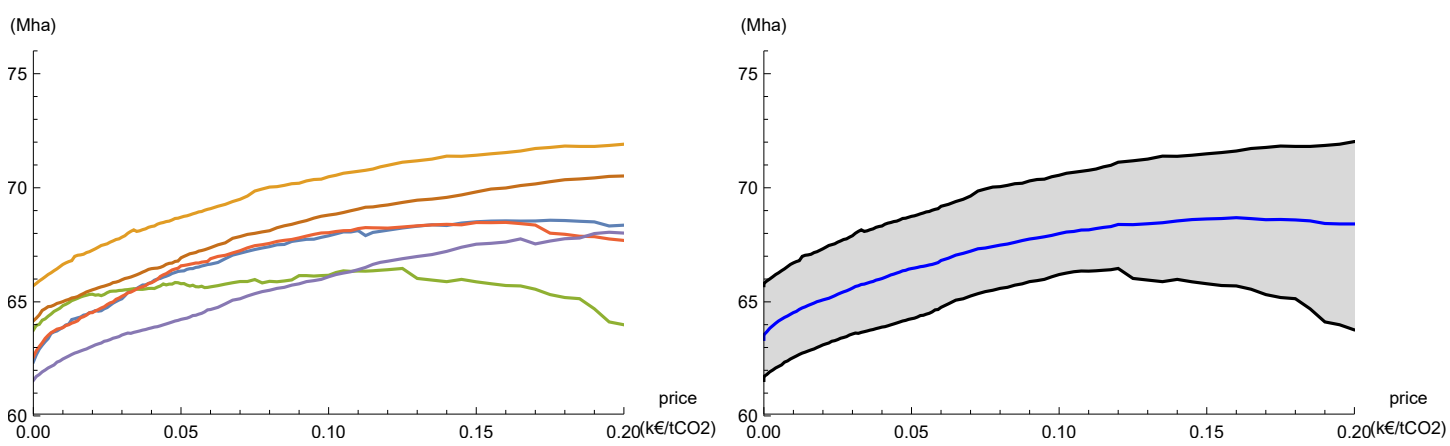

(a) Cereal area

harvested cereals - UE-27 (AROPAj V5-2007-2012)

harvested cereals - UE-27 (AROPAj V5-2007-2012)
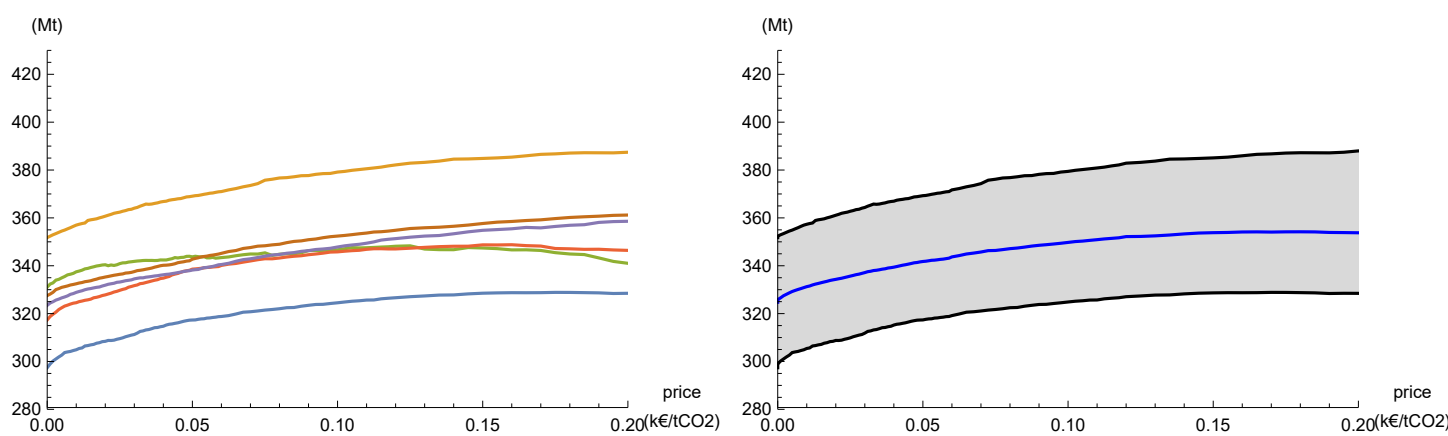

(b) Total cereal production

marketed cereals - UE-27 (AROPAj V5-2007-2012)

marketed cereals - UE-27 (AROPAj V5-2007-2012)
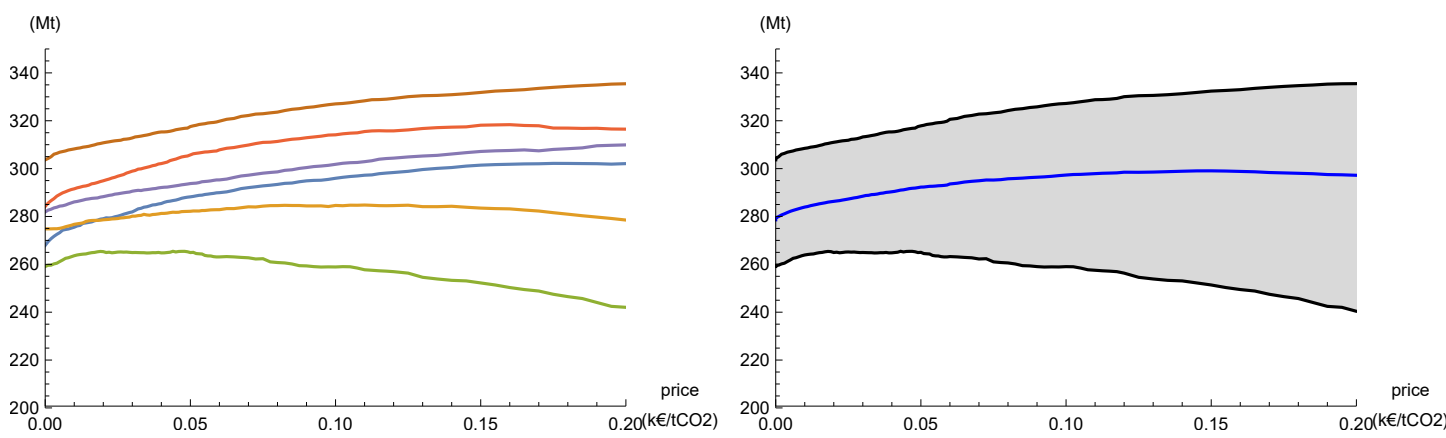

(c) Marketed cereal production

on-farm used cereals - UE-27 (AROPAj V5-2007-2012)

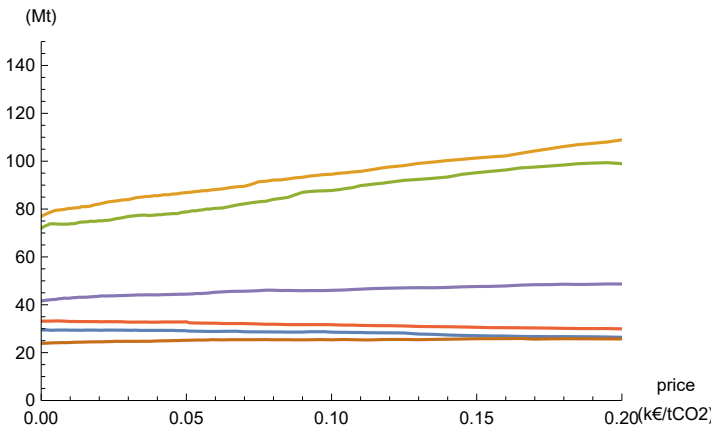

on-farm used cereals - UE-27 (AROPAj V5-2007-2012)

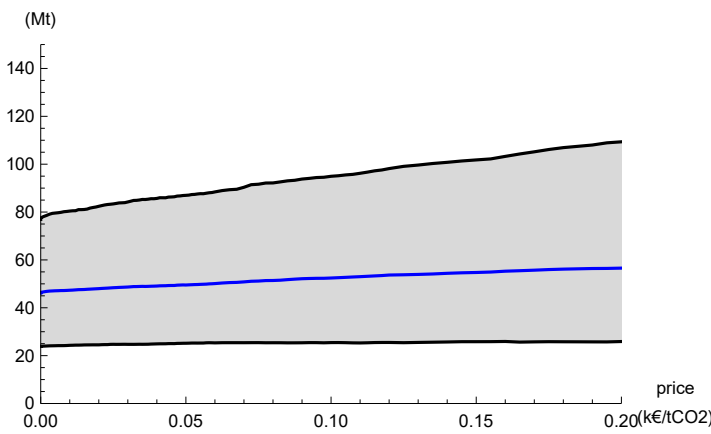

(d) On-farm used cereal production

$-2007-2008-2009-2010-2011-2012$

Figure 1. Results from the AROPAj model version based on the six FADN years (2007-2012). 

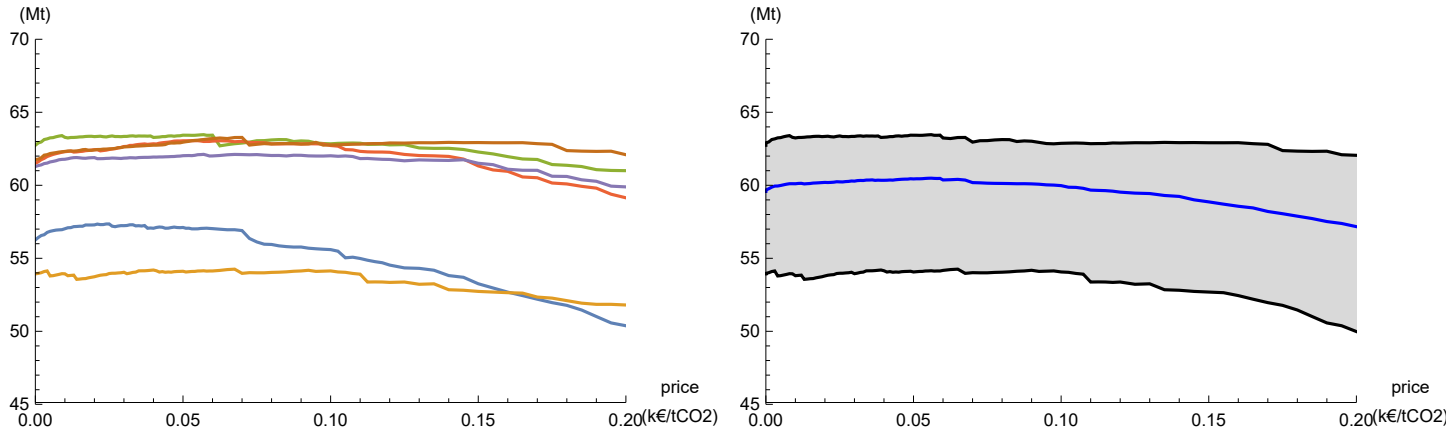

(e) Marketed oleoproteins production

oleoprotein area - UE-27 (AROPAj V5-2007-2012)

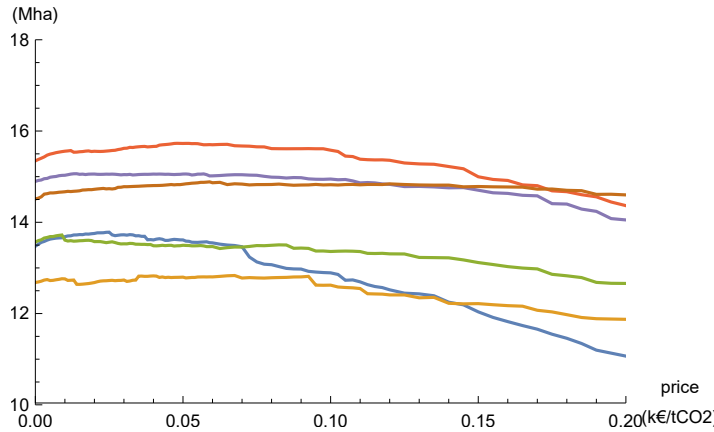

(f) Marketed oleoproteins area oleoprotein area - UE-27 (AROPAj V5-2007-2012)

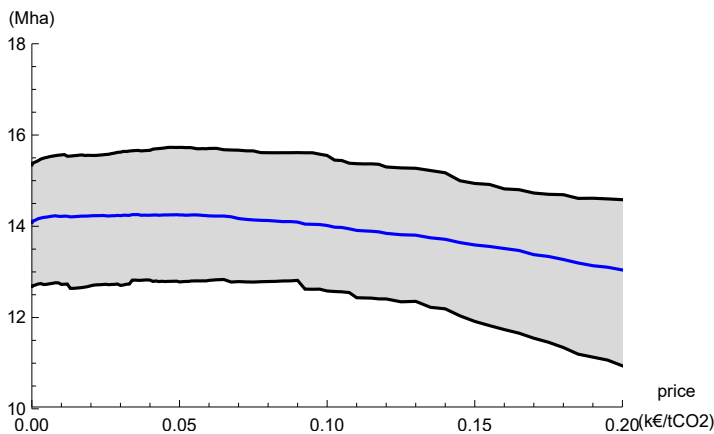

meat production - UE-27 (AROPAj V5-2007-2012)
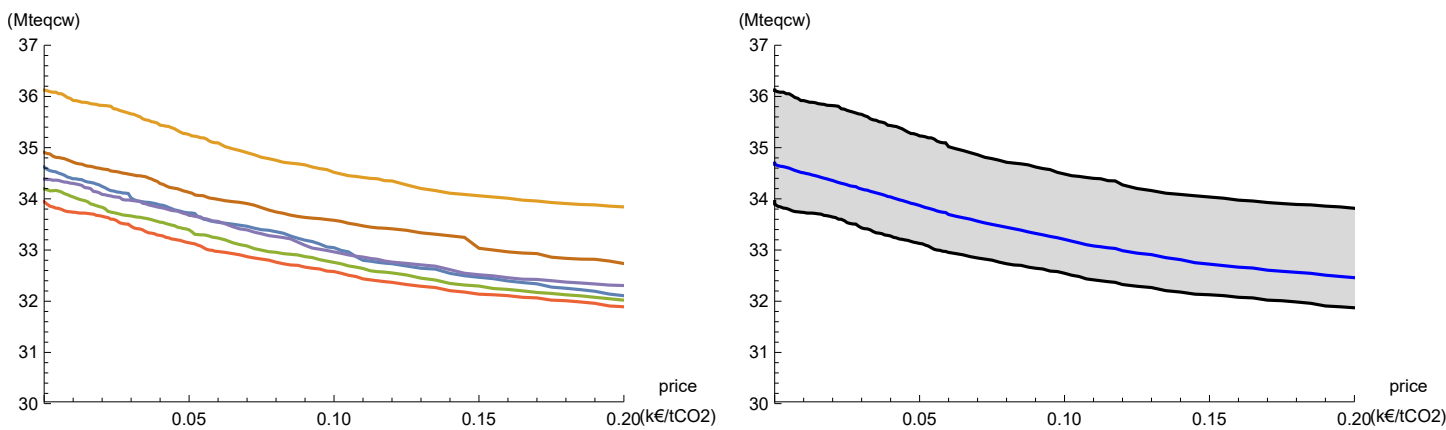

(g) Meat production

Concentrated feed - UE-27 (AROPAj V5-2007-2012)

Concentrated feed - UE-27 (AROPAj V5-2007-2012)
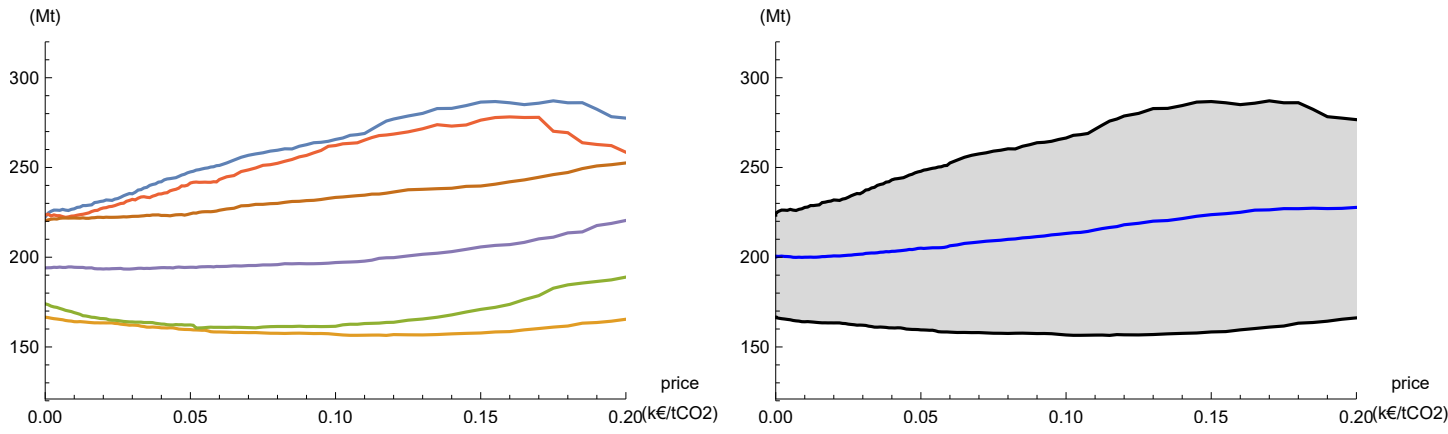

(h) Concentrated feed

Figure 1 continued. Results from the AROPAj model version based on the six FADN years (2007-2012). 
limit here can differ substantially from the peak's price limit in the case of marketed production (see Figure 1a). This result combines the effect of the relative change in the use of production (on-farm vs market), the effect of the substantial change in the global price system and cross-price effect between feed sources, and the effect of the annual change in meteorological conditions. Figure 1a also provides the envelope interval for the six years curves. Given the carbon price, when the six-year-based general conditions are assumed to occur with the same probability, the peak for cereal area is obtained at a price of around $160 € / \mathrm{tCO}_{2}$ (see the blue curve, referring to the value averaged over the years). This is far above the price observed in the $\mathrm{CO}_{2}$ market over the past years. The price level at which this change occurs depends on the year.

The key point here is that, on average, a peak in cereal land allocation and in the marketed part of production is obtained when the carbon price is around $150 € / \mathrm{tCO}_{2} \mathrm{eq}$, when the livestock adjustment is substantial but moderate $(+/-25 \%)$. The peak shifts toward a higher carbon price in the case of on-farm re-use of cereals for feed. This reflects the complex relationships between cropping and breeding activities through feed and different parts of feed, typically on-farm cereals (Figure 1d), fodders and meadows, and concentrated feed (Figure 1h). The cases of oleoproteins area and production (Figures 1f and 1e) reinforce the statement that interference with animal feed represents one of the aspects of the trade-off between crop and animal productions.

As shown above, the EU harvested cereal production, representing the sum of marketed and on-farm used cereal productions, exhibited a strong variation during 2007-2012, with a peak in 2008. If we introduce a carbon tax, the harvested cereal production increases until a certain price level, after which it starts to decrease. For 2007, 2009, and 2010, this price level lies in the range [125 €, $180 €$ ] (see Figure 1b). For 2008, 2011 and 2012, this change occurs outside the price scope.

Animal production decreases with the carbon price, with an impact on the demand for feed (fodder, concentrated feed, and on-farm cereals). Therefore, in contrast to crop production, which increases, animal production continuously decreases when the carbon price increases. Figure $1 \mathrm{~g}$ illustrates the decline in the EU meat supply (expressed in carcass weight equivalent, teqcw accounting for metric ton), with the same decreasing slope for each of the six years. Figure $1 \mathrm{~g}$ reveals that the reduction of meat production is characterized by an average decrease of about 2 Mteqcw over the entire carbon price range.

Figure 2 shows the effects of introducing a GHG emission tax of $200 € / \mathrm{tCO}_{2}$ on marketed feed, marketed cereals, and on-farm used cereals in the EU for a livestock adjustment of $25 \%$ from 2007-2012. The quantity of on-farm used cereals, regardless of the carbon tax level, which had a positive but insignificant influence, peaked in 2008 ( $77 \mathrm{Mt}$ when there is no tax and $109 \mathrm{Mt}$ for a EUR 200 tax), after which it fell sharply to more than two-thirds in 2012 (24 Mt when there is no tax and $26 \mathrm{Mt}$ for a EUR 200 tax). In contrast, the quantities of marketed cereals and marketed feed exhibited a large decrease in 2009, after which they started to increase again. This can be explained by the fluctuation of global cereal prices (with a large decline in 2009 as a result of the 2008 crisis), a drop in animal numbers, and the water scarcity in 2008.

Changes in the area dedicated to major crops vs carbon price are illustrated in Figure 3 for the six years examined (2007-2012). A tax increase implies a decrease in grasslands and fodders area in the EU and a strong increase in fallows area. Even if land allocations differ across years, major crops resist carbon pricing to some extent, when fodders and more strongly permanent meadows are dramatically affected. Animal production suffers from strong penalties on fermentation-generated $\mathrm{CH}_{4}$ emission involving ruminants, as well as manure-generated $\mathrm{N}_{2} \mathrm{O}$ emission involving cattle as a whole.

The spatial distribution of the areas cultivated with different crops is illustrated by the maps of area proportions among all crops considered in AROPAj, for different emission tax levels. Figures 4 and 5 illustrate the proportion of the areas cultivated with cereals, as well as the permanent meadows, reported to the AROPAj UAA.

other cereals. 

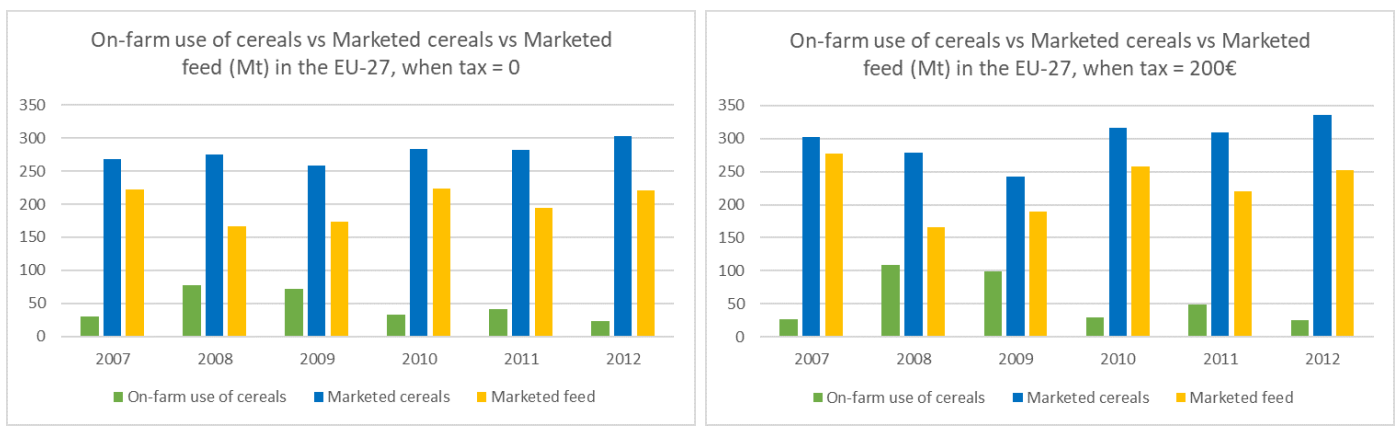

Figure 2. Marketed feed vs Marketed cereals vs On-farm used cereals (expressed in Mt), for the no tax situation and for a EUR 200 emission tax.

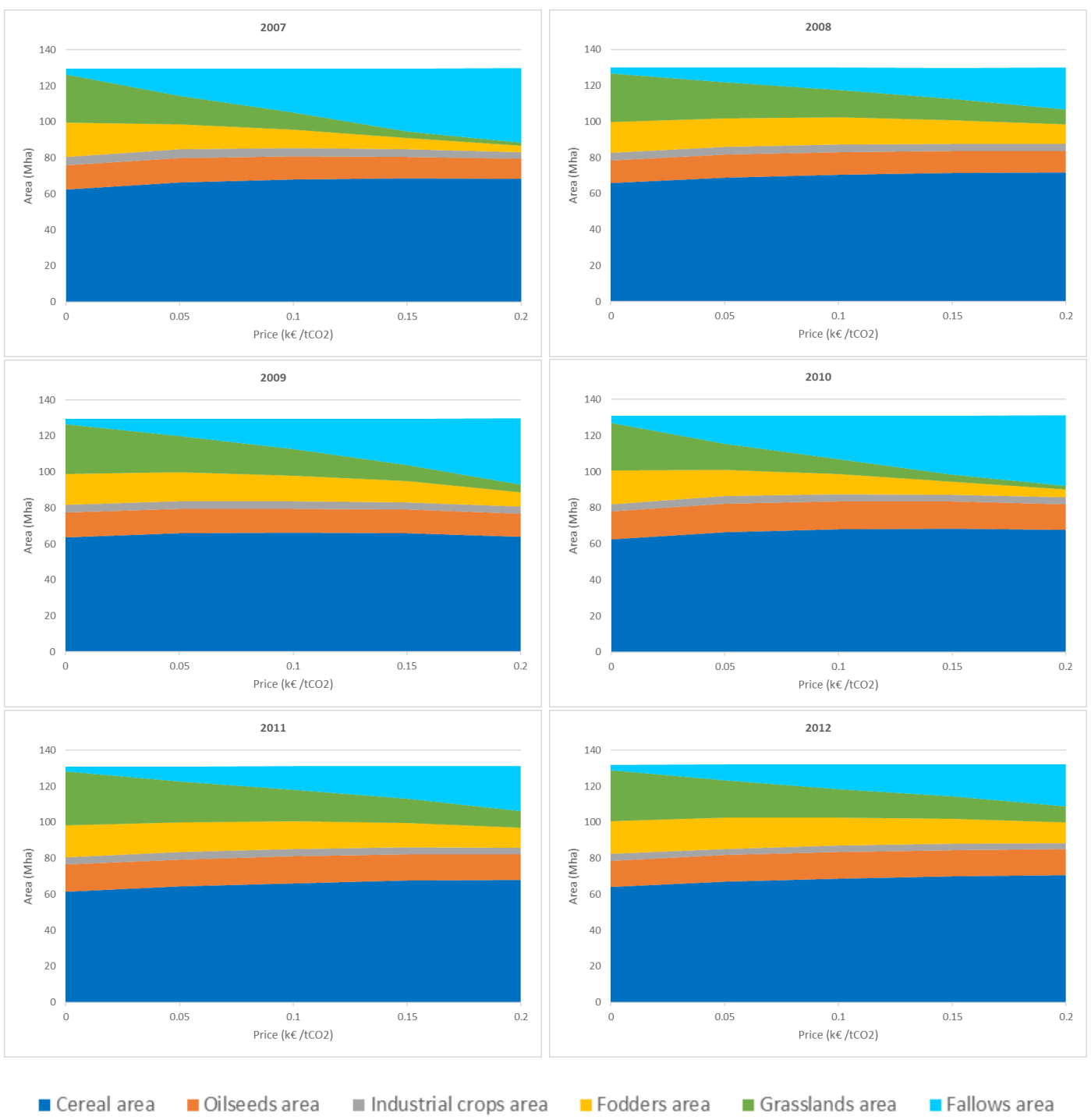

Figure 3. Trends in the areas of major crops vs $\mathrm{CO}_{2}$ price in the $\mathrm{EU}$ (2007-2012 FADN years - AROPAj). 

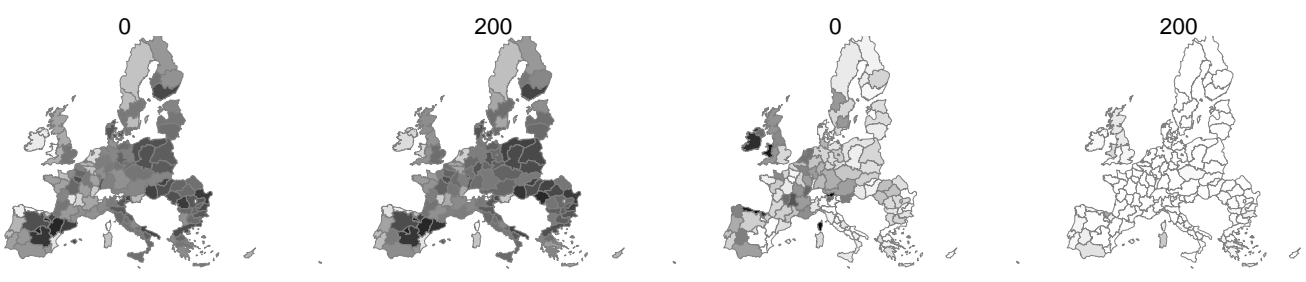

2007
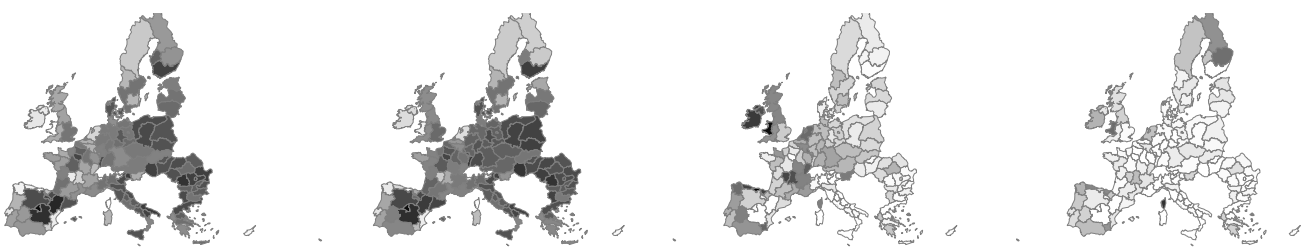

2008
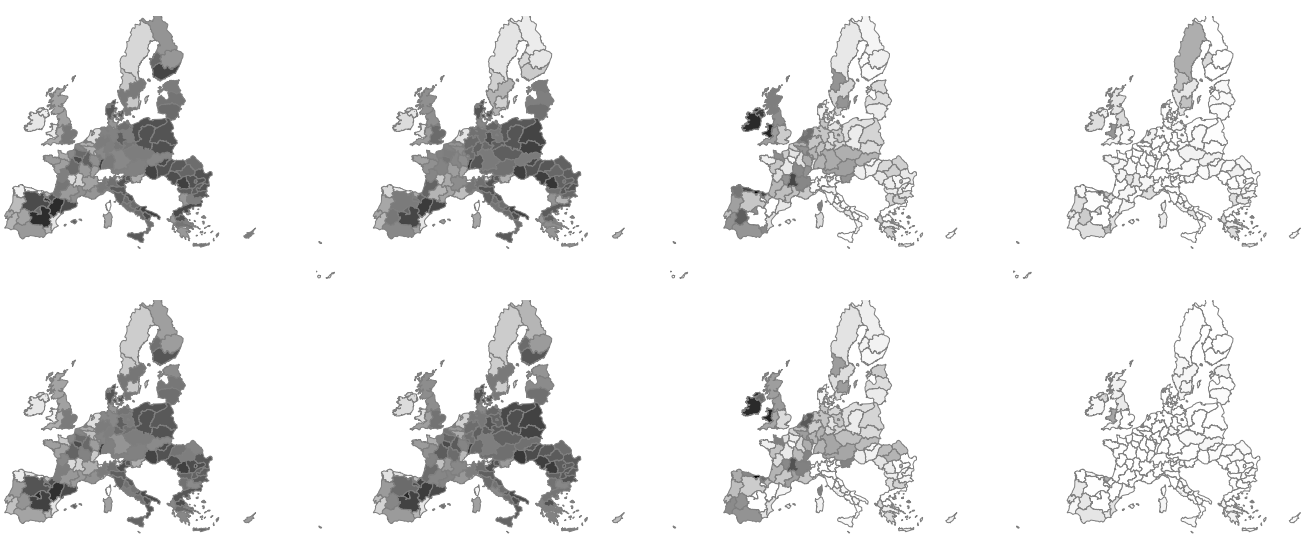

2010
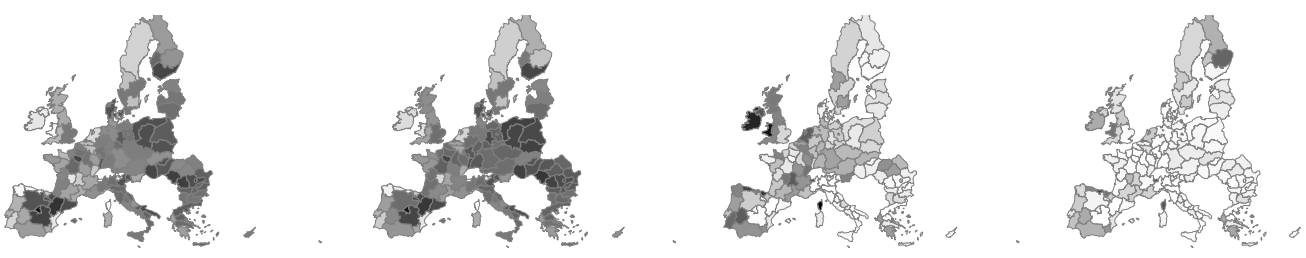

2009
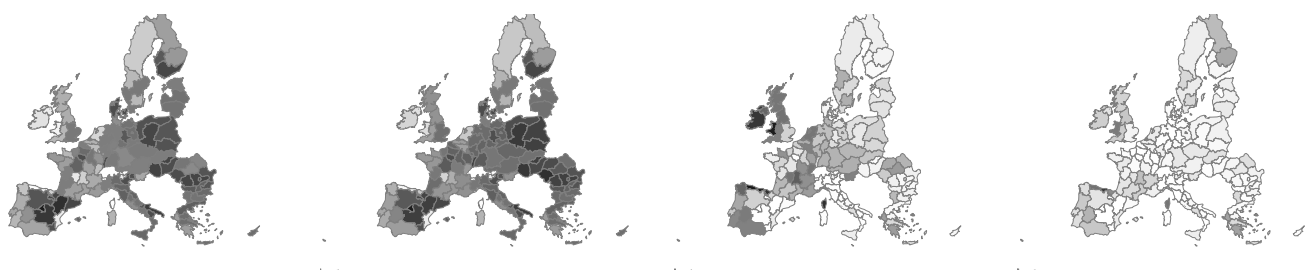

2011
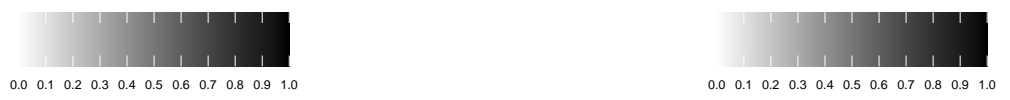

Figure 4. Proportion of total straw cereals area in the EU (2007-2012) for two carbon tax values: EUR 0 (on the left) and EUR 200 (on the right).

Figure 5. Proportion of permanent meadows area in the EU (2007-2012) for two carbon tax values: EUR 0 (on the left) and EUR 200 (on the right). 
Marketed crops areas, and mainly cereals areas, resist almost homogenously across the entire European agricultural system when the carbon price increases, whereas meadows are strongly affected, due to their connection to animal productions, especially cattle. This would mainly affect the westernmost part of Europe as well as Central Europe. With the abandonment of grasslands being largely compensated by adoption of fallow land, the agricultural landscape could be substantially modified and differently so across different European regions. The analysis of the carbon price impact over the six years examined, highlights a form of robustness in the allocation of land across years, although the AROPAj typology is conducted completely independently in each year.

\subsection{Food calorie target impact}

We introduced different calorie quantity thresholds, ranging from 165 to $555 \mathrm{Mtsweq}$, and conducted the calculations for the six years against which the model is calibrated. As expected, a feasible solution of the mathematical programming model depends on the year. For a dual price of 0 , the quantities of calories from 2007 to 2012 vary between $166 \mathrm{Mt}$ and $227 \mathrm{Mt}$ (see Table 3). Applying an increasing threshold of calories leads to an increase in the dual price. If we introduce the different targets of calorie quantities of 300,350, and 400 Mtsweq, the dual price varies in the ranges [ $20 €, 36 €],[27 €, 52 €]$, and [36€,94€], respectively. The dual price rises to a maximum value corresponding to the maximum production thresholds, beyond which the solution obtained is no longer feasible. Figure 6 illustrates the net quantity of food, as the dual price rises to EUR 250. These dual prices can be compared to marketed soft wheat prices, which, for French representative farms in cereal regions, were, on average, EUR 170, EUR 140, EUR 110, EUR 170, EUR 180, EUR 210 per ton, respectively, for 2007, 2008, 2009, 2010, 2011, and 2012. Differences between years reflect the heterogeneous economic and meteorological conditions prevailing each year in the period from 2007 to 2012.

Table 3. Calorie quantities (Mt soft wheat equivalent) and other calorie indicators for the six FADN years (2007-2012).

\begin{tabular}{l|cccccc} 
FADN year & $\mathbf{2 0 0 7}$ & $\mathbf{2 0 0 8}$ & $\mathbf{2 0 0 9}$ & $\mathbf{2 0 1 0}$ & $\mathbf{2 0 1 1}$ & $\mathbf{2 0 1 2}$ \\
\hline unconstrained estimate (Mtsweq*) & 166 & 227 & 219 & 183 & 218 & 204 \\
feasibility limit (Mtsweq) & 450 & 530 & 550 & 500 & 505 & 505 \\
dual price limit (€/tsweq) & 1920 & 1244 & 1889 & 1284 & 1525 & 1974 \\
dual price for 300 Mtsweq threshold & 25 & 26 & 20 & 25 & 29 & 36 \\
dual price for 350 Mtsweq threshold & 52 & 32 & 27 & 30 & 34 & 44 \\
dual price for 400 Mtsweq threshold & 94 & 49 & 36 & 51 & 72 & 83 \\
reference soft wheat price** $(€ /$ t) & 170 & 140 & 110 & 170 & 180 & 210 \\
limit/reference ratio & 2.6 & 3.8 & 5 & 2.9 & 2.8 & 2.4 \\
\hline
\end{tabular}

* Million tons of soft wheat equivalent.

** reference price: average of soft wheat prices in the French Centre region.

In Figure 7, we illustrate how the land sharing among the different groups of crops (on the $y$-axis) varies from the quantities of human calories provided by the EU farming system (on the $\mathrm{x}$-axis) in the six years. The results differ significantly across the years, when considering the gaps between the unbounded case and the feasibility limit case on the one hand, and between years in terms of the quantity shift from left to right (on the x-axis) on the other hand. However, the trends in land allocation when changing the calorie quantity limit appear robust across the six years. It should be noted that the EU potential calorie limit estimated by the AROPAj model varies from $450 \mathrm{Mt}$ up to $550 \mathrm{Mt}$, expressed in equivalent soft wheat over the six years, rising from 2.5 to 5 times the basic calibrated case level.

The gain in calorie production is mainly due to transfers from animal sources (milk and meat) toward cereals, oilseeds, and protein crops. Another key aspect emerges through changes 


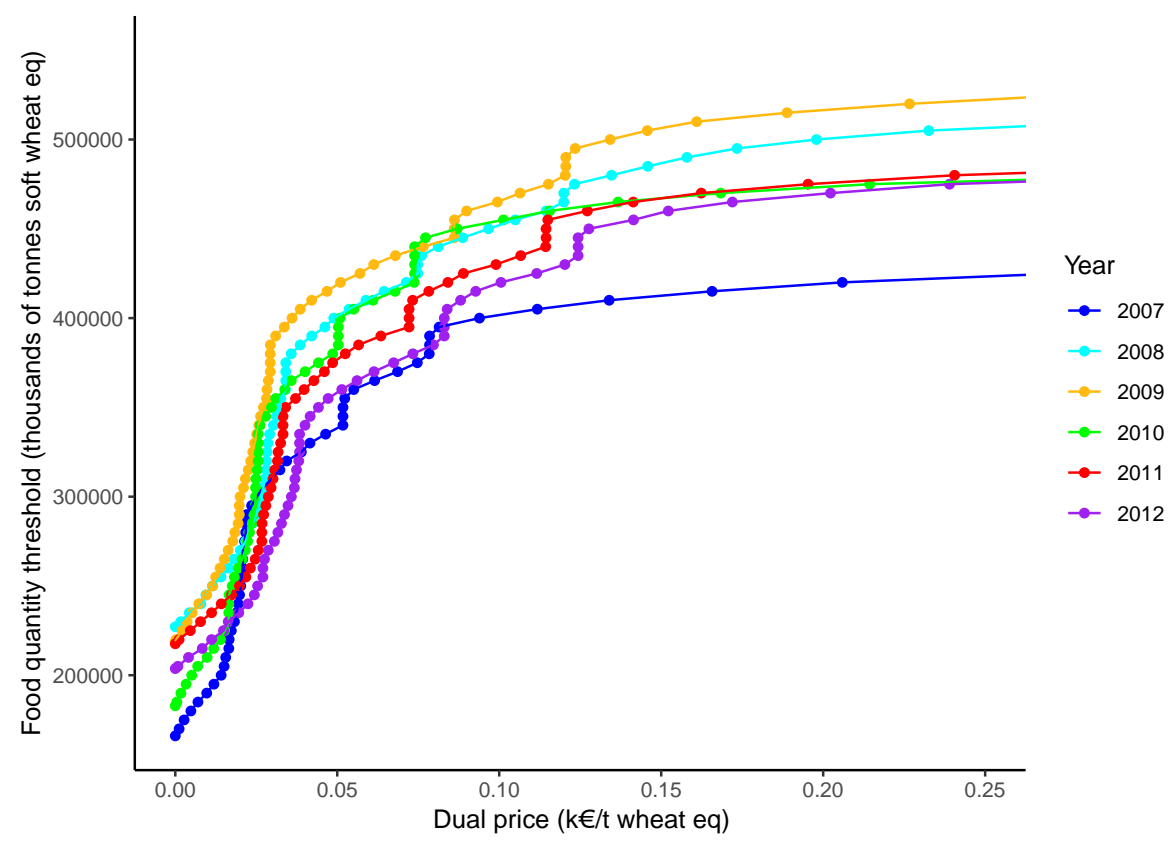

Figure 6. Net quantity of food vs dual price.

in the animal diet by recalling that, in the model, on-farm cereals, concentrate feed, and pasture account for feeding.

We detail the analysis regarding livestock (see Figures 8 and 9). In our simulations, livestock is allowed to be adjusted within a limit of $+/-25 \%$ with respect to the basic case. Considering that unchanged prices may be in favor of some animal categories in the unbounded calorie threshold case, the gap of concerned livestock categories may reach $50 \%$ over the interval of calorie targets from the unbounded case to the upper limit case. We illustrate changes for two emblematic categories, namely, beef cows and milk cows. Although the number of beef cows varies regularly as the calorie target increases, the number of milk cows follows a different path of weaker amplitude and decreases irregularly. The milk quota system associated with guaranteed prices and premiums, applied in the period from 2007 to 2012 matters substantially.

The impact of introducing a calorie production target on total GHG emissions highlights a regular decrease of emissions as the calorie target increases (see Figure 10). Depending on the year, an increase of the food production target from 230 Mtsweq to 435 Mtsweq, would lead to a decrease in emissions ranging from $26 \mathrm{MtCO}_{2} \mathrm{eq}(7 \%)$ to $75 \mathrm{MtCO}_{2} \mathrm{eq}(20 \%)$.

Given the diversity of farming systems across the EU, we investigate the results at the regional level. To this end, we consider areas dedicated to straw cereals on the one hand and to permanent meadows on the other hand. Proportions of the area shared between these two categories are mapped for each of the six years and for two cases: the reference case and a calorie target of 435 million tons of soft wheat equivalent (Figure 11 refers to cereals and 12 to meadows).

Supporting the aggregated land sharing illustrated in Figure 7, there is no apparent difference between the regions across the EU in terms of land dedicated to straw cereals (Figure 11). None or almost none of the regions decrease the land dedicated to cereals. However, focusing on the land occupied by meadows reveals that regions differ significantly in terms of land sharing when calorie targets are ambitious. Some western and central European regions may suffer from a cattle decline revealed through a decrease in grassland (e.g., northwest France and southeast England, and south Germany and Austria). Knowing that fallows should replace grasslands (as shown in Figure 7), increasing the target of net calorie production may affect the activity in some rich agricultural regions. 


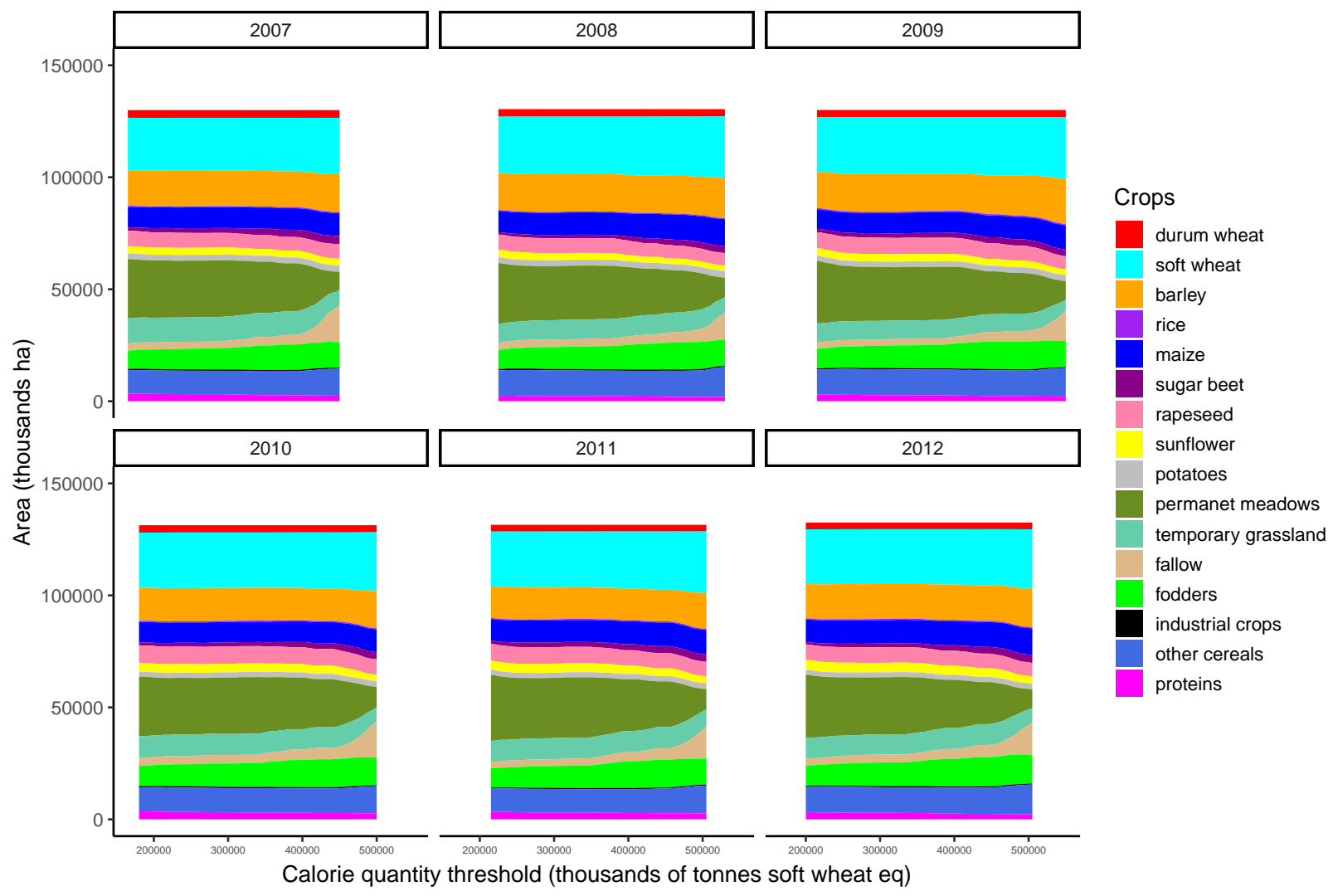

Figure 7. Trends in areas of major crops by calorie quantity threshold
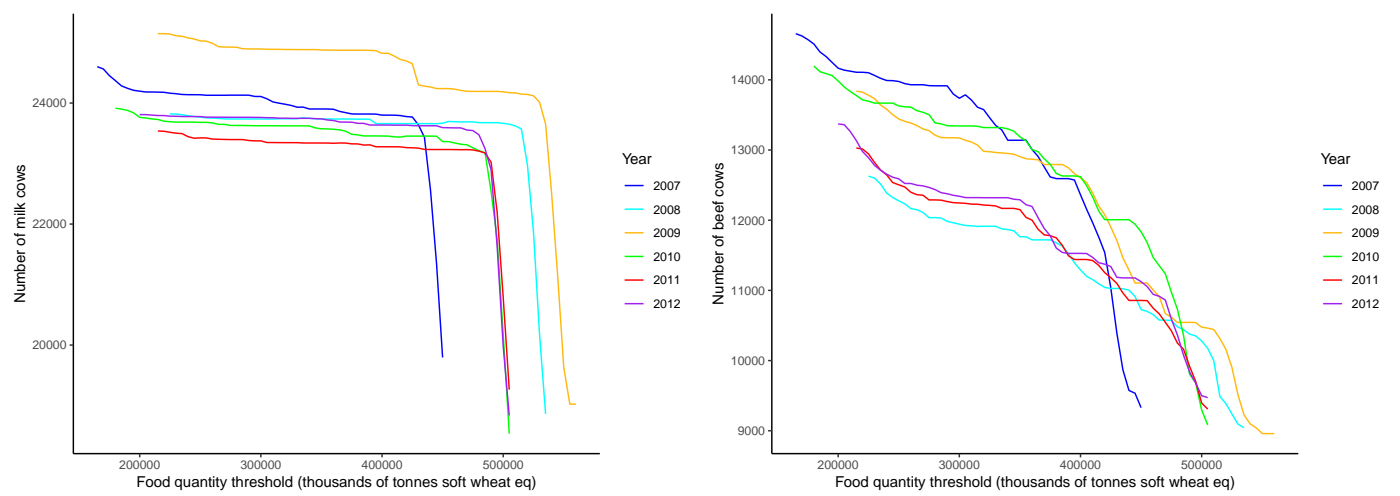

Figure 8. Trends in the number of milk cows as Figure 9. Trends in the number of beef cows as the calorie threshold increases. the calorie threshold increases. 


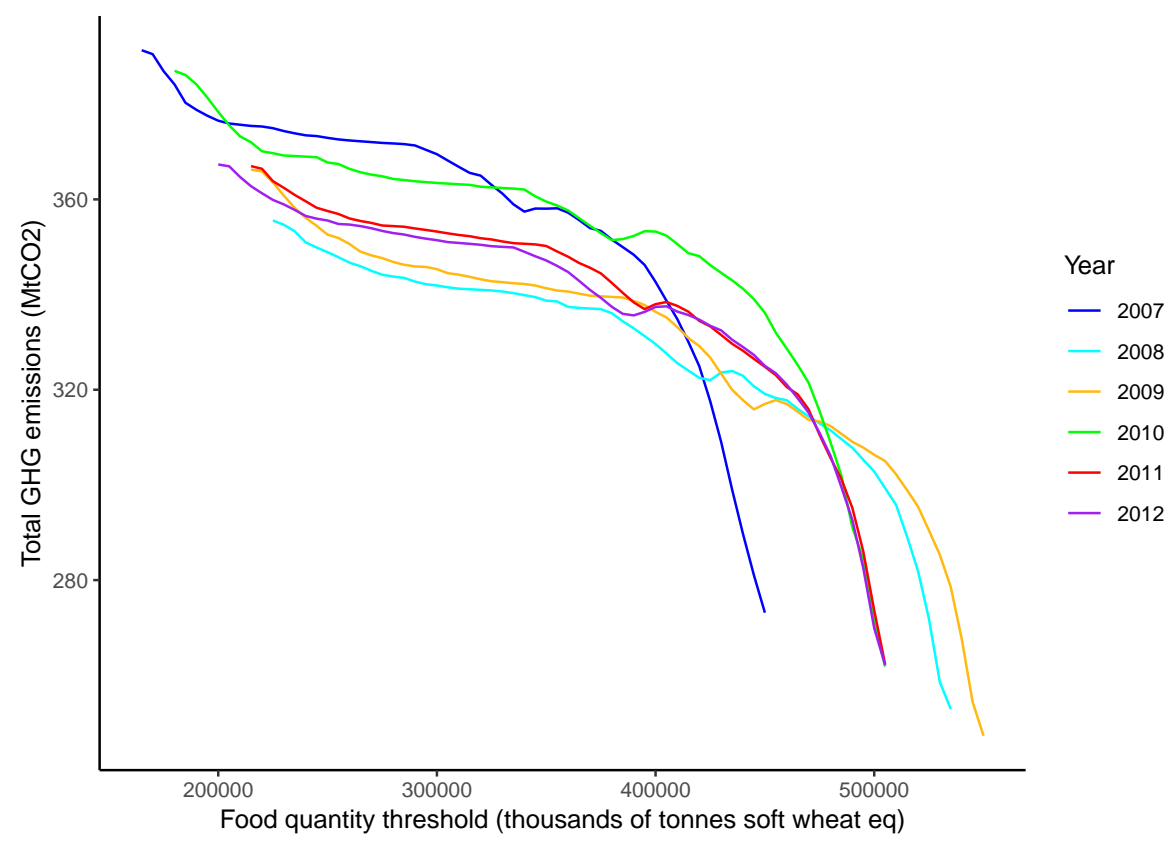

Figure 10. Trends in the total GHG emissions as the calorie threshold increases.

\section{Discussion for policy implications}

\subsection{Scope of results}

Our methodological framework relies on the principle "simulate and average", unlike many other models, whose simulations assume the use of the average values of the parameters. The analysis is conducted for six-years of diverse economic and meteorological contexts, as an example remarkably characterized by the doubling of cereal prices over the period. That does not prevent against the lack of all feedback effects that could enrich the analysis. The first type of feedback would be price changes resulting from market clearing, and the other would be climate feedback and technical progress induced by a large change in the European agricultural supply. Nevertheless, the amplitude of observed economic changes for which the model accounts makes our analysis valuable. The important point is that results are provided in technically and economically viable (observed) conditions.

The six versions are each based on a classification of samples into representative farms carried out independently of each other. The same applies to the calibration of each version. The structure of the agricultural system represented appears stable, despite the biases still attributable to the quality of the FADN samples and despite the biases inherent in the AROPAj model. For example, the UAA represented by AROPAj, of the order of 131 Mha, offers an interannual relative standard deviation of $0.7 \%$, and the livestock, of $101 \mathrm{MLU}$, a standard deviation of $0.9 \%$. This structural stability does not prevent greater variability in the areas occupied by the different activities, from $2.1 \%$ for common wheat to $26.2 \%$ for soybeans (and $3.9 \%$ for all 9 cereals represented by the model, for an average surface of $64.4 \mathrm{Mha}$ ). This variability, partly accentuated because it is a mathematical programming model, mainly reflects the variability of prices and weather conditions. And still realistically, the production of net food calories and greenhouse gas emissions accentuate the effects of the economic and meteorological environment. In the calibration solution for the 6 years, the calorie production is on average $186.5 \mathrm{Mt}$ common wheat equivalent, with a relative standard deviation of $10.6 \%$, and the total direct GHG emissions are estimated on average at $364.1 \mathrm{Mt} \mathrm{CO}_{2}$ with a standard deviation of $2.5 \%$ (210.5 and 153.6 respectively for methane and nitrogen oxide, with $1.4 \%$ and $5.2 \%$ as standard deviations, respectively). The results used in our analysis are based on the hypothesis of the inter-age balance of the cattle herd with an adjustment 

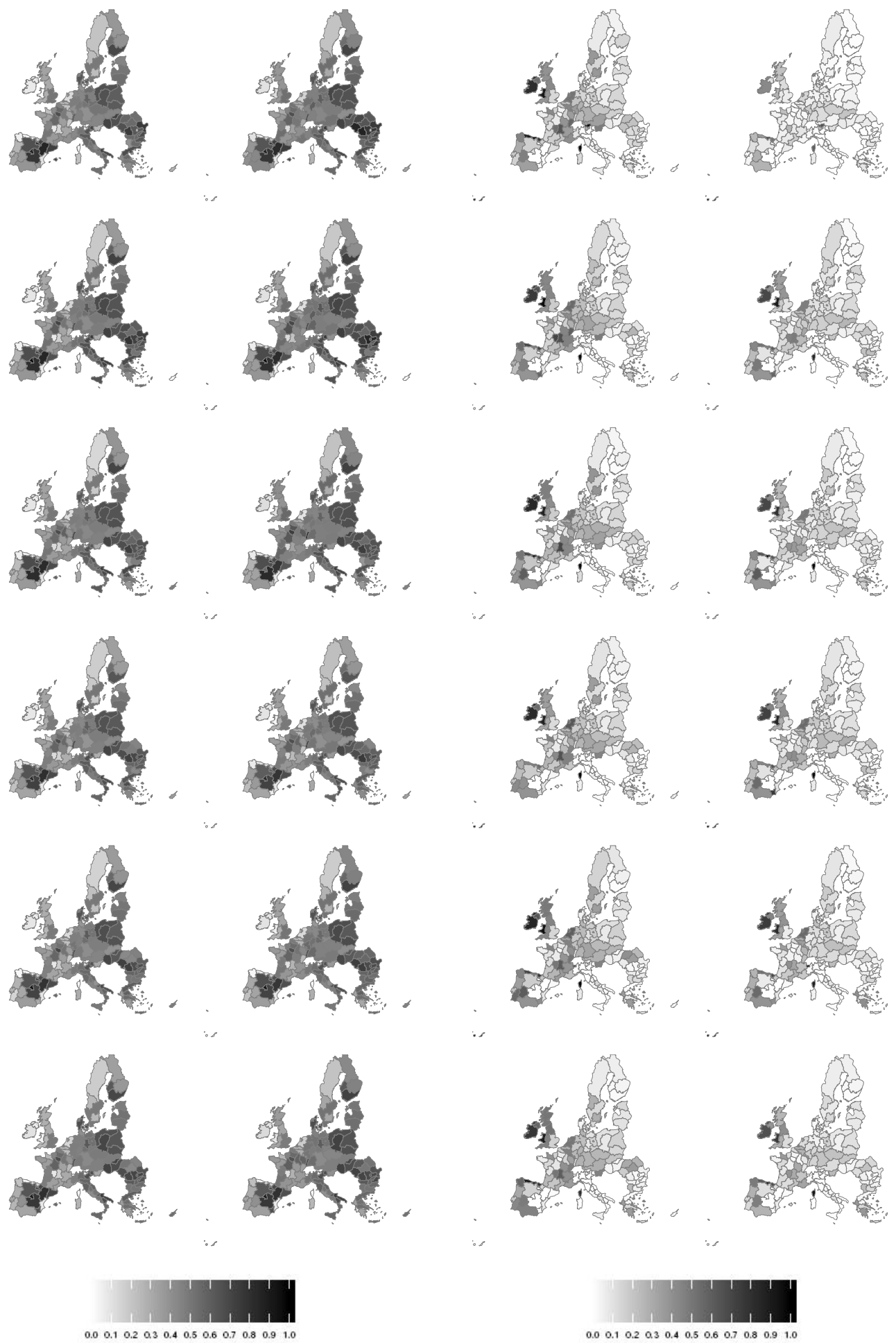

Figure 11. Proportion of total straw cereals area in the EU (2007-2012) for no threshold (on the left), and after the introduction of a threshold of 435 Mtsweq (on the right).

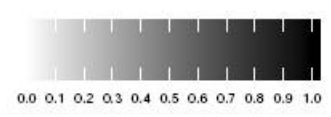

Figure 12. Proportion of permanent meadows area in the EU (2007-2012) for no threshold (on the left), and after the introduction of a threshold of 435 Mtsweq (on the right). 
of the animal capital varying in an interval fixed as a percentage of the initial capital. At zero carbon price and in the absence of any calorie production threshold, the livestock lag resulting from an adjustment rate of $25 \%$ is $1.3 \%$.

In the EU, a carbon price of EUR 200 would reduce GHG emissions from $273 \mathrm{Mt}$ to $239 \mathrm{Mt}$ and increase the abatement rates from $25 \%$ to $39 \%$, depending on the year, given that the annual base emissions also vary significantly (from $356 \mathrm{Mt}$ to $391 \mathrm{Mt}$ ). By letting this price vary across the entire interval considered, [0,200], crop productions increase to some extent, and eventually decrease but much less than animal productions, which decline normally when the $\mathrm{CO}_{2}$ price increases. This result is reinforced when we assign to the sector an increasing production of food calories. The food objective is achieved by reducing GHG emissions, to the detriment of animal production and by considerably modifying the mode of animal feeding. This translates into a sharp reduction in the area under grass, partially offset by an increase in the area under marketed crops, but also by a significant increase in the area under fallow. By striving to reach an ambitious goal of producing food calories, it could be more costly to maintain animal productions consuming plants than to suppress these productions, at least in certain regions, including regions dominated by animal husbandry. The regional analysis (mapping) carried out above (see Figures 11 and 12) illustrates this result. If it appears possible, in the light of the results, to double the production of calories on average without upsetting the balance between animal and vegetable production too much, an additional effort still possible of around 50\% (compared to reference production) very substantially alters this balance, and in all cases animal feed is the key to change.

\subsection{Policy implications}

We investigated the compatibility of two goals frequently supported by policy-makers, underlined in European Commission guidelines and boosted as general common objectives. The goals, namely, stabilizing or even increasing food production and decreasing agricultural impact on the environment are expressed in our analysis via the net supply of calories for the human diet on the one hand and via the abatement of GHG emissions on the other hand.

The margin offered to secure the production of calories in the EU is potentially significant, the net production of calories being able to be two and a half times higher while remaining within the framework of the economic and technical environment of the years 2007-2012. It is therefore technically and economically realistic. But to reach this level, one would have to expect major changes in terms of agricultural land use associated mainly with changes and especially with the decrease in the quantities of food ingested by a declining herd.

Even if it can always be argued that a significant change in agricultural production concerning 130 Mha would significantly impact the physical and economic environment in the absence of economic regulation, it should be noted that (i) with regard to the physical environment through the lens of climate change, the significant reduction in GHG emissions associated with the disruption of production resulting from simulations is both explained and realistic; (ii) with regard to the economic environment, in particular the reaction of agricultural prices to changes in European supply, it is important to remember that agricultural prices have been framed for several decades of agricultural policy, proving that political will would make an ambitious quantitative goal of producing food calories possible.

The evolution of food consumption under the effect of changes in consumer choices, accompanied or amplified by public health policies, is a determining factor for the future of the agricultural sector. It is also a determining factor in terms of human impact on the global environment, in particular the climate via agricultural GHG emissions. Even if our study only focuses on the supply of the agricultural sector alone and its direct GHG emissions, it intersects the field covered by three policies, namely food policy, agricultural policy, climate policy. We can assess, even briefly, some of the terms of social welfare taken into account by the public decision-makers in charge of these policies. 
In this regard, let us specify the basic elements of the calculation. The European agricultural gross margin, from one year to another over the period 2007-2012, varies from EUR 126.0 to 165.8 billion, with an average of EUR 149.6 billion (relative standard deviation of 9.2\%), including support for CAP size from EUR 40.8 to 44.6 billion (on average 43.4, with a standard deviation of $3.4 \%$ ).

Consider the year 2012, to fix things. Under the technical and economic conditions of the year, it is mathematically possible to go from a production of food calories from 200 to 500 Mtsweq, which would result in a reduction in GHG emissions of $97 \mathrm{MtCO}_{2}$, going from 367 to $270 \mathrm{MtCO}_{2}$ eq. The remaining emissions, valued at EUR 210 (which is the price of $\mathrm{CO}_{2}$ allowing this reduction, all other things being equal), the "valuation" of emissions at the marginal cost of reduction is EUR 57 billion. By implementing a $\mathrm{CO}_{2}$ pricing policy, the livestock adjustment ratio being 25\%, the gross margin is reduced by EUR 66 billion. The marginal value of the last calorie produced, when producing $500 \mathrm{Mtsweq}$, is greater than $1000 € / \mathrm{tsweq}$, about five times the price of common wheat paid to the producer in France in 2012, while the European gross margin goes from EUR 176 to 110 billion, and GHG emissions from 367 to $270 \mathrm{MtCO}$. To lower GHG emissions by $97 \mathrm{MtCO}_{2}$ only by "taxing" GHG emissions (when no calorie production threshold applies), the price per tonne of $\mathrm{CO}_{2}$ eq would be EUR 210, with a loss of EUR 65 billion in gross margin (from 175.6 to 110.6), and a tax proceeds of EUR 57 billion. In this case, the net cost (gross margin difference increased by the tax proceeds) would be EUR 8 billion, logically lower than the loss of gross margin of EUR 31 billion which would result from an obligation to produce $500 \mathrm{Mtsweq}$ in net food calories.

At a more moderate level of dual food calorie price, close in soft wheat equivalent to the price of common wheat in French production, the potential for calorie production is estimated at $470 \mathrm{Mtsweq}$, and the associated fall in emissions of GHG to around $52 \mathrm{MtCO}_{2} e q$. The corresponding decrease in gross margin is estimated at EUR 16 billion. Achieving the same level of reduction in GHG emissions of $52 \mathrm{MtCO}_{2} e q$ by carbon pricing would be obtained with a $\mathrm{CO}_{2}$-price of 81.5 $€ / t \mathrm{CO}_{2} e q$. At this price, GHG emissions are "valued" at EUR 25.7 billion (the carbon tax proceeds), with a drop in gross margin of EUR 27.5 billion, and a net social cost (margin differential increased by the differential of tax proceeds) of EUR 1.8 billion. From an environmental point of view, for a reduction in GHG emissions of $52 \mathrm{MtCO}_{2}$ (or approximately $15 \%$ of emissions estimated for 2012), the difference in social cost between the "food calorie target" option and the "carbon price" option (the least expensive because it directly targets GHG emissions) is EUR 14 billion. The decline in livestock, all animal categories combined, is significant. It is $12 \%$ with the "food calorie target" option and $8.5 \%$ with the "carbon policy" option.

Table 4 summarizes the elements making it possible to compare the effects of a policy aimed at increasing the production of food calories and a policy of pricing GHG emissions leading to an equivalent reduction in GHG emissions. The calculations are made for two levels of calorie production, respectively $500 \mathrm{Mtsweq}$ (close to the technically feasible maximum) and $470 \mathrm{Mtsweq}$, based on the year 2012 .

Within the European Union, a policy aimed at reducing agricultural GHG emissions as a priority would therefore have a significant effect on animal production, just like a policy aimed at increasing net production of food calories. The public health policy is outside the scope of this study, it would therefore remain to assess what could be the social benefits of a human diet in balance with an agricultural offer evolving towards crop production while diverting somewhat from animal production. What is shown here is an example of the positive cross-effects that a policy can have on a domain other than its own. If positive results clearly emerge at European level, at local level the negative effects on agricultural activity could be very significant, in particular in regions where few alternatives to animal production exist. To mitigate these negative effects, among the political options that could emerge, in addition to promoting the quality of animal products (viable if prices rise substantially), we find the promotion of bio-energies from plants that are difficult to transform into human food. Switchgrass is a candidate plant to be transformed 
Table 4. Targeting calorie production vs pricing GHG emissions given first the calorie target and second the level of GHG emissions (computations for 2012, in millions of tonnes of $\mathrm{CO}_{2}$ equivalent) for two calorie targets (in millions of tonnes of soft wheat equivalent); quantity surplus estimated in billion $€$; livestock deviation estimated in $\%$ of the average.

\begin{tabular}{l|cc|c}
\hline calorie target & 470 & 500 & $\left(\mathrm{M} t_{\text {sweq }}\right)$ \\
dual price related to the calorie target & 202 & 1080 & $\left(€ / t_{\text {sweq }}\right)$ \\
\hline GHG emissions related to the calorie target & 315 & 270 & $\left(\mathrm{MtCO} \mathrm{O}_{2} \mathrm{eq}\right)$ \\
GHG abatement related to the calorie target & 52 & 97 & $\left(\mathrm{MtCO} \mathrm{C}_{2} \mathrm{eq}\right)$ \\
$\mathrm{CO}_{2}$ price corresponding to the GHG emission abatement & 81.5 & 210. & $\left(€ / \mathrm{t} \mathrm{CO}_{2} \mathrm{eq}\right)$ \\
without calorie target limit & & & \\
\hline gross margin loss (food calorie policy) & 16 & 31 & (billion $€)$ \\
\hline gross margin loss $\left(\mathrm{CO}_{2}\right.$ pricing policy) & 27.5 & 65.0 & $($ billion $€)$ \\
$\mathrm{CO}_{2}$ tax receipt $\left(\mathrm{CO}_{2}\right.$ pricing policy) & 25.7 & 56.7 & (billion $€)$ \\
net loss when $\mathrm{CO}_{2}$ pricing & 1.8 & 8.3 & $($ billion $€)$ \\
\hline livestock decrease (food calorie policy) & 12.0 & 22.3 & $(\%)$ \\
livestock decrease $\left(\mathrm{CO}_{2}\right.$ policy) & 8.5 & 14.7 & $(\%)$ \\
\hline net production of food calorie $\left(\mathrm{CO}_{2}\right.$ pricing policy) & 205 & 184 & $\left(\mathrm{M} t_{\text {sweq }}\right)$ \\
\hline
\end{tabular}

\footnotetext{
${ }^{8}$ https://www.insee.fr/fr/statistiques
} plants.

\section{Conclusion}

into liquid agrofuels, while other productions are the preferred substrates for anaerobic digestion

Diet trends could be powerful drivers of change in the agricultural production sector. According to the European Public Health Association (2017), while European food consumption varies from country to country, most countries are trying to move towards a healthy diet that respects the environment. Although meat remains an important item in the food basket, the amount of meat consumed has decreased since the $1980 \mathrm{~s}^{8}$. If the average EU diet were to approach healthier levels, animal production and therefore pasture and concentrated food would be reduced and land would be freed up for agricultural production. Our analysis even shows that a significant part of the land could become fallow when animal production systems offer few prospects for reconversion. In addition, reducing food waste would further reduce pressure on the land, and work in progress shows that increased agricultural production could widen outlets for bio-energy. The evolution of the diet and the pressure exerted by securing the production of food calories or the wider outlets offered for the energy recovery of agricultural products and co-products have significant impacts on the environment. Greenhouse gas emissions from agriculture could decrease by 25 to $30 \%$ if the farming system were called upon to maximize the production of food calories.

Conversely, seeking to reduce greenhouse gas emissions by pricing GHG emissions will obviously have significant impacts on the production of agriculture and livestock. Up to a high level of this price - let's keep 200 euros per tonne of GHG in carbon dioxide equivalent - plant production increases or decreases slightly while animal production (mainly meat, then milk) decreases significantly. Our results show that here again animal feed plays a key role, while pricing greenhouse gas emissions impacts the consumption of synthetic nitrogen fertilizers in a direction and in a different amplitude than what is obtained in seeking to increase the production of calories. The importance of livestock in the adjustment of agricultural production systems is also verified with GHG emissions, since, up to $€ 200$ per tonne of $\mathrm{CO} 2$ equivalent, the reduction in methane emissions is twice as high as reduction of nitrous oxide emissions. 
Increasing European production of food calories would result in an increase in plant production and a decrease in animal production in significant proportions, with a significant reduction in European agricultural GHG emissions. Putting a price on agricultural GHG emissions obviously leads to a reduction in GHG emissions, by affecting the production of livestock systems while allowing crop production to be maintained, at least as long as the price of GHG remains below EUR 200 per tonne of $\mathrm{CO}_{2}$-equivalent. The objective of increasing calorie production and the objective of reducing GHG emissions are therefore compatible, one appearing as a co-benefit of the other. Our results are one contribution among others to the multi-criteria evaluation of different components of public policies. We can illustrate the entanglement and the complexity of the political choice through the criteria that the AROPAj model makes it possible to assess, by focusing on the gross agricultural margin and some criteria that can be associated with the challenges of public health and environment.

Let us retain the emblematic value of EUR 100 per tonne of CO2-equivalent that we would apply to methane and nitrous oxide emissions, in a scenario where the number of animals in the main categories of livestock can vary over the interval from $-25 \%$ to $+25 \%$ of the initial value. Based on $2012 \mathrm{FADN}$ data, the fall in emissions is $16 \%$ (-59MtCO $2 \mathrm{eq})$, the value of the remaining emissions is EUR 30.8 billion (tax revenue), the fall in agricultural gross margin is 19\% (-33.3 billion) and the loss of gross margin less tax revenue is EUR 2.5 billion. The associated impacts are an increase in the net production of food calories by $1 \%$, a fall in livestock by $9.8 \%$, a drop in area devoted to permanent meadows by $44 \%$, and a decrease in the consumption of synthetic fertilizers by $3.3 \%$. The reductions in GHG emissions are respectively $9.3 \%$ for $\mathrm{N}_{2} \mathrm{O}$ and $20.5 \%$ for $\mathrm{CH}_{4}$. Let us now consider, with the same range of variation in livestock, the level of food calories corresponding to a drop in GHG emissions of 16\%, a level estimated at 480 million tonnes of common wheat in calorie equivalent $(+240 \%)$. In return for this production effort, the drop in gross margin is estimated at 18 billion euros $(-10.3 \%)$. The herd decreases by $13.7 \%$ and the area under permanent meadows by $53 \%$. The consumption of synthetic fertilizers increased by $9.7 \%$.

For a given level of GHG emissions, the two options lead to very contrasting values on the criteria of agricultural gross margin, production of food calories, animal production, allocation of land and consumption of synthetic fertilizers. These different criteria, among others, should be taken into account to integrate the impacts on health and the environment into public choices. The interest of the economic model of European agriculture used in the analysis is to be able to estimate these criteria under realistic economic and technical conditions. Although costly in computing, the analysis will be enriched by determining the frontier of what European agriculture can offer in terms of production of food calories, production of bio-energies, GHG emissions and consumption of synthetic fertilizers.

\section{References}

Adelphi (2018). The Carbon Tax in Sweden. Technical report, Fact sheet for: Federal Ministry for the Environment, Nature Conservation and Nuclear Safety (BMU).

Aldy, J. E. \& Stavins, R. N. (2012). The Promise and Problems of Pricing Carbon: Theory and Experience. The Journal of Environment and Development, 21(2).

Bajzelj, B., Richards, K., Allwood, J., Smith, P., Dennis, J., Curmi, E., \& Gilligan, C. (2014). Importance of food-demand management for climate mitigation. Nature Climate Change, 4 , 924-929.

Beddington, J., Asaduzzaman, M., Fernández, A., Clark, M., Guillou, M., Jahn, M., Erda, L., Mamo, T., Van Bo, N., Nobre, C., Scholes, R., Sharma, R., \& Wakhungu, J. (2012). Achieving 
food security in the face of climate change: Final report from the Commission on Sustainable Agriculture and Climate Change. Technical report, CGIAR Research Program on Climate Change, Agriculture and Food Security (CCAFS). Copenhagen, Denmark.

Berners-Lee, M., Kennelly, C., Watson, R., \& Hewitt, C. N. (2018). Current global food production is sufficient to meet human nutritional needs in 2050 provided there is radical societal adaptation. Elem Sci Anth, 6(1).

De Cara, S., Henry, L., \& Jayet, P.-A. (2018). Optimal coverage of an emission tax in the presence of monitoring, reporting, and verification costs. Journal of Environmental Economics and Management, 89, 1-13.

De Cara, S., Houzé, M., \& Jayet, P.-A. (2005). Methane and Nitrous Oxide Emissions from Agriculture in the EU: A Spatial Assessment of Sources and Abatement Costs. Environmental \& Resource Economics, 32, 551-583.

De Cara, S. \& Jayet, P.-A. (2011). Marginal abatement costs of greenhouse gas emissions from European agriculture, cost effectiveness, and the EU non-ETS burden sharing agreement. Ecological Economics, 70, 1680-1690.

Deering, K. (2014). Stepping up to the challenge - Six Issues facing global climate change and food security. Technical report, Copenhagen, Wageningen: CARE, CGIAR Research Program on Climate Change, Agriculture and Food Security (CCAFS), Technical Centre for Agricultural and Rural Cooperation (CTA).

Devereux, S. \& Edwards, J. (2004). Climate Change and Food Security. IDS Bulletin, 35(3), $22-30$.

European Commission (2009). EU 2009 Report on Policy Coherence for Development. Technical report, European Commission.

European Commission (2013). Agriculture in the European Union - statistical and economic information. Technical report, European Commission, Directorate General for Agriculture and Rural Development.

European Commission (2014). EU cereal farms report 2013 based on FADN data. Technical report, European Commission.

European Commission (2017). EU Agricultural Outlook for the EU Agricultural Markets and Income 2017-2030. Technical report, European Commission.

European Environment Agency (2019). Annual European Union greenhouse gas inventory 1990-2017 and inventory report 2019. Submission under the United Nations Framework Convention on Climate Change and the Kyoto Protocol. Technical report, EEA/PUBL/2019/051.

European Public Health Association (2017). Healthy and Sustainable Diets for European Countries. Technical report, EUPHA.

FAO (2003a). Les bilans alimentaires. Organisation des Nations Unies pour l'alimentation et l'agriculture.

FAO (2003b). Trade reforms and food security: conceptualizing the linkages. Technical report, Food and Agriculture Organization of the United Nations.

FAO (2009). Food Security and Agricultural Mitigation in Developing Countries: Options for Capturing Synergies. Technical report, Food and Agriculture Organization of the United Nations. 
Foley, J., Ramankutty, N., Brauman, K., Cassidy, E., Gerber, J., Johnston, M., Mueller, N., O’Connell, C., Ray, D., West, P., Balzer, C., Bennett, E., Carpenter, S., Hill, J., Monfreda, C., Polasky, S., Rockström, J., Sheehan, J., Siebert, S., \& Zaks, D. (2011). Solutions for a Cultivated Planet. Nature, 478, 337-342.

Frank, S., Havlík, P., Soussana, J.-F., Levesque, A., Valin, H., Wollenberg, E., Kleinwechter, U., Fricko, O., Gusti, M., Herrero, M., Smith, P., Hasegawa, T., Kraxner, F., \& Obersteiner, M. (2017). Reducing greenhouse gas emissions in agriculture without compromising food security? Environ. Res. Lett., 12, 105004.

Galko, E. \& Jayet, P.-A. (2011). Economic and environmental effects of decoupled agricultural support in the EU. Agricultural Economics, 42, 605-618.

Garnett, T. (2011). Where are the best opportunities for reducing greenhouse gas emissions in the food system (including the food chain)? Food Policy, 36.

Gerber, P., Steinfeld, H., Henderson, B., Mottet, A., Opio, C., Dijkman, J., Falcucci, A., \& Tempio, G. (2013). Tackling climate change through livestock - A global assessment of emissions and mitigation opportunities. Technical report, Food and Agriculture Organization of the United Nations (FAO), Rome.

Godfray, H. C. J. (2014). The challenge of feeding 9-10 billion people equitably and sustainably. The Journal of Agricultural Science, 152, 2-8.

Gregory, P., Ingram, J., \& Brklacich, M. (2005). Climate change and food security. Philosophical transactions of the Royal Society of London. Series B, Biological sciences.

Havlík, P., Valin, H., Herrero, M., Obersteiner, M., Schmid, E., Rufino, M., Mosnier, A., Thornton, P., Böttcher, H., Conant, R., Frank, S., Fritz, S., Fuss, S., Kraxner, F., \& Notenbaert, A. (2014). Climate change mitigation through livestock system transitions. PNAS, 111(10), 3709-3714.

HLPE (2012). Food security and climate change. A report by the High Level Panel of Experts on Food Security and Nutrition of the Committee on World Food Security. Technical report, High Level Panel of Experts on Food Security and Nutrition (HLPE).

Huyghe, C., De Vliegher, A., van Gils, B., \& Peeters, A. (2014). Grasslands and herbivore production in Europe and effects of common policies. Éditions Quæ.

IPCC (2006). 2006 IPCC Guidelines for National Greenhouse Gas Inventories Volume 4: Agriculture, Forestry and Other Land Use. Chapter 5: CROPLAND. Technical report, Intergovernmental Panel on Climate Change.

Kossoy, A., Peszko, G., Oppermann, K., Prytz, N., Gilbert, A., Klein, N., Lam, L., \& Wong, L. (2015). Carbon pricing watch 2015 : an advance brief from the state and trends of carbon pricing 2015 report, to be released late 2015. State and Trends of Carbon Pricing. Technical report, Washington, D.C. : World Bank Group.

Leip, A., Weiss, F., Wassenaar, T., Perez, I., Fellmann, T., Loudjani, P., Tubiello, F., Grandgirard, D., Monni, S., \& Biala, K. (2010). Evaluation of the livestock sector's contribution to the EU greenhouse gas emissions (GGELS). Technical report, European Commission, Joint Research Centre.

Ludi, E. (2009). Climate change, water and food security. Overseas Development Institute.

McAllister, T., Beauchemin, K., McGinn, S., Hao, X., \& Robinson, P. (2011). Greenhouse gases in animal agriculture-Finding a balance between food production and emissions. Animal Feed Science and Technology, 166-167, 1-6. 
Meijl, v., Havlik, P., Lotze-Campen, H., Stehfest, E., Witzke, P., Domınguez, I. P., Bodirsky, B., Dijk, v., Doelman, J., Fellmann, T., Humpenoder, F., Koopman, J., Muller, C., Popp, A., Tabeau, A., Valin, H., \& van Zeist, W. (2018). Comparing impacts of climate change and mitigation on global agriculture by 2050. Environ. Res. Lett., 13(064021).

OECD (2015). Agriculture and Climate Change. Technical report, OECD.

OECD and WBG (2015). The FASTER Principles for Successful Carbon Pricing: An approach based on initial experience. Technical report, Organisation for Economic Cooperation and Development (OECD) and World Bank Group (WBG).

Olesen, J. \& Bindi, M. (2002). Consequences of climate change for European agricultural productivity, land use and policy. European Journal of Agronomy, 16, 239-262.

O'Mara, F. (2012). The role of grasslands in food security and climate change. Annals of Botany, $110,1263-1270$.

Röös, E., Bajželj, B., Smith, P., Patel, M., Little, D., \& Garnett, T. (2017). Greedy or needy? Land use and climate impacts of food in 2050 under different livestock futures. Global Environmental Change, 47.

Smith, P., Haberl, H., Popp, A., Erb, K.-h., Lauk, C., Harper, R., Tubiello, F. N., de Siqueira Pinto, A., Jafari, M., Sohi, S., Masera, O., Böttcher, H., Berndes, G., Bustamante, M., Ahammad, H., Clark, H., Dong, H., Elsiddig, E. A., Mbow, C., Ravindranath, N. H., Rice, C. W., Robledo Abad, C., Romanovskaya, A., Sperling, F., Herrero, M., House, J. I., \& Rose, S. (2013). How much land-based greenhouse gas mitigation can be achieved without compromising food security and environmental goals? Global Change Biology, 19, 2285-2302.

Smith, P., Martino, D., Cai, Z., Gwary, D., Janzen, H., Kumar, P., McCarl, B., Ogle, S., O’Mara, F., Rice, C., Scholes, B., Sirotenko, O., Howden, M., McAllister, T., Pan, G., Romanenkov, V., Schneider, U., Towprayoon, S., Wattenbach, M., \& Smith, J. (2008). Greenhouse gas mitigation in agriculture. Philosophical Transactions of the Royal Society $B$.

Sonesson, U., Davis, J., \& Ziegler, F. (2010). Food production and emissions of greenhouse gases - An overview of the climate impact of different product groups. Technical report, SIK - the Swedish Institute for Food and Biotechnology.

The Grantham Research Institute (2011). Briefing Note: The case for carbon pricing. Technical report, The Grantham Research Institute on Climate Change and the Environment.

Tilman, D. \& Clark, M. (2014). Global diets link environmentalsustainability and human health. Nature, 515.

United Nations (2015). Transforming our world: the 2030 Agenda for Sustainable Development. Technical report, United Nations.

van Kernebeek, H. R. J., Oosting, S. J., van Ittersum, M. K., Bikker, P., \& Boer, I. J. M. D. (2016). Saving land to feed a growing population: consequences for consumption of crop and livestock products. Int J Life Cycle Assess, 21, 677-687.

Vojtech, V. (2010). Policy Measures Addressing Agrienvironmental Issues. Technical report, OECD Food, Agriculture and Fisheries Papers, No. 24, OECD Publishing, Paris.

West, P. C., Gerber, J. S., Engstrom, P. M., Mueller, N. D., Brauman, K. A., Carlson, K. M., Cassidy, E. S., Johnston, M., K., G., MacDonald, Ray, D. K., \& Siebert, S. (2014). Leverage points for improving global food security and the environment. Science, 345. 
771 Wilkes, A., Tennigkeit, T., \& Solymosi, K. (2013). National planning for GHG mitigation in 772 agriculture: A guidance document. Technical report, Food and Agiculture Organization of the 773 United Nations (FAO).

774 World Bank and Ecofys (2018). State and Trends of Carbon Pricing 2018. Technical report, World 775 Bank, Washington, DC. 